\title{
Ações Afirmativas nos Governos FHC e Lula: um Balanço ${ }^{1}$
}

Sales Augusto dos Santos ${ }^{2}$

Neste artigo, buscaremos demonstrar que tanto para a administração Fernando Henrique Cardoso (FHC), de orientação pró-mercado ou neoliberal, quanto para a administração Lula, de orientação pró-políticas sociais, a questão racial e/ou as desigualdades raciais (que afetam expressivamente a população negra), assim como as propostas de combate ao racismo, não foram prioridade em suas agendas. Palavras-chave: Ação afirmativa; Educação Pública Superior; Governo FHC; Governo Lula.

\section{Affirmative Action in the Presidencies of FHC and Lula: an Evaluation}

\section{Abstract}

In this article, the author seeks to demonstrate that neither during the administration of Fernando Henrique Cardoso (FHC), its pro-market or neoliberal agenda, nor during the Lula administration, with its pro-social policy orientation, the issue of race and/or the racial inequalities (which specifically affect the black population) and the proposals to combat racism, were not priorities.

Keywords: Affirmative action; Public higher education; Cardoso administration; Lula administration

\footnotetext{
${ }^{1}$ Uma versão anterior deste artigo, cujo título era "Between Left and Right, the Descendents of Slaves in Brazil Remain Black?" foi apresentada na Conference on Global Affirmative Action in a Neoliberal Age, organizada pelo Center for African and African American Research at Duke University, que foi realizada de 08 a 10 de novembro de 2012, na Duke University. Mais ainda, uma versão do primeiro item deste artigo foi publicada em SANTOS, Sales Augusto dos; e SILVEIRA, Marly. "Políticas de Promoção da Igualdade Racial e Ação Afirmativa”. Salto para o Futuro, v. 12, 2010.

${ }^{2}$ Doutor em Sociologia pela Universidade de Brasília (UnB), com Pós-Doutorado pela Brown University. Membro do Núcleo de Estudos Afro-Brasileiros da UnB e professor de Sociologia da Escola de Ciências Jurídicas da Faculdade Projeção do Distrito Federal.
} 


\section{Introdução}

No Brasil, o debate sobre políticas de ação afirmativa recebe, nos últimos quinze anos, adensamento em escala razoável tanto no campo político como no acadêmico. A luta dos movimentos sociais negros brasileiros, associada à conjuntura internacional de renovação da pauta de combate ao racismo, manifestada na III Conferência Mundial contra o Racismo, Discriminação Racial, Xenofobia e Intolerância Correlata, realizada em Durban, África do Sul, no ano de 2001, fortaleceu, no Brasil, a discussão sobre a necessidade de implementação de políticas focalizadas na população negra. Assim, a partir do início do século XXI, a questão racial definitivamente foi incluída agenda nacional brasileira.

Mais do que isso, a execução de algumas políticas de ação afirmativa no Brasil passou a ser ponto de litígio justiça. Ou seja, esse processo não aconteceu sem resistência de setores conservadores da sociedade brasileira. Em setembro de 2009, o Partido Democratas (DEM) ${ }^{3}$, ajuizou, no Supremo Tribunal Federal

\footnotetext{
${ }^{3}$ Esse partido político era o antigo Partido da Frente Liberal (PFL), com ideologia de direita, que foi fundado em 24 de janeiro de 1985, logo após o fim formal da ditadura militar no Brasil (de 1964 a 1985). Em 28 de março de 2007 o PFL mudou de nome e passou a se chamar Democratas (DEM). Deve-se destacar também que o PFL era uma dissidência do antigo Partido Democrático Social (PDS), que apoiou a ditadura militar supracitada. Esse último foi sucessor da antiga Aliança Renovadora Nacional (ARENA). Como se pode observar, as raízes históricas ou, caso se queira, a história, do DEM indicam que ele é um partido político de direita e tem posições conservadoras no que diz respeito a avanços sociais, políticos, educacionais, culturais, econômicos e democráticos, entre outros, no Brasil. Em última instância, as suas origens são aristocráticas e escravocratas. E não foi sem sentido e sem suporte partidário que o então senador Demóstenes Torres (DEM/GO), numa audiência pública no STF para debater a constitucionalidade do sistema de cotas para estudantes negros nas universidades públicas, em 3 de março de 2010, posicionando-se contra esse sistema, demonstrou uma certa mentalidade escravista. Ao se referir ao nosso processo de miscigenação, e evocando o sociólogo Gilberto Freyre, aquele que é considerado o principal ideólogo do mito da democracia racial brasileira, esse ex-senador afirmou que: "Nós temos uma história tão bonita de miscigenação (...). [Fala-se que] as negras foram estupradas no Brasil. [Fala-se que] a miscigenação deu-se no Brasil pelo estupro. [Fala-se que] foi algo forçado. Gilberto Freyre, que é hoje renegado, mostra que isso se deu de forma muito mais consensual". Extraído de: http://www1.
} 
$(\mathrm{STF})^{4}$, a Arguição de Descumprimento de Preceito Fundamental (ADPF) n.o 186. Nela, o DEM, baseando-se e apoiando-se em argumentos de alguns intelectuais brasileiros ${ }^{5}$, questionou judicialmente a política de ação afirmativa para estudantes negros implementada pela Universidade de Brasília (UnB), por meio do sistema de cotas.

Essa ADPF foi considerada improcedente pelos dez ministros do STF que participaram do seu julgamento, nos dias 25 e 26 de abril de 2012. Todos os magistrados desse tribunal entenderam ser "harmônica com a Carta Federal, com os direitos fundamentais nela previstos, a adoção temporária e proporcional às necessidades, do sistema de quotas para ingresso em universidades públicas, considerados brancos e negros." (MELLO, 2012, p. 11)

folha.uol.com.br/folha/educacao/ult305u702198.shtml. Acessado em 10 de janeiro de 2011. Deve-se ressaltar que o ex-senador Demóstenes Torres foi cassado, pelo Senado Federal, no dia 11 de julho de 2012, por quebra de decoro parlamentar, ante a sua ligação com o crime organizado no Brasil. Extraído de: http://g1.globo.com/jornal-hoje/noticia/2012/07/senador-demostenes-torres-e-cassado-pelo-plenario-do-senado.html. Acessado em 11 de julho de 2012.

4 “O Supremo Tribunal Federal é o órgão de cúpula do Poder Judiciário, e a ele compete, precipuamente, a guarda da Constituição, conforme definido no art. 102 da Constituição Federal. O Supremo Tribunal Federal é composto por onze Ministros, brasileiros natos (art. 12, § 3ํ, IV, da CF/88), escolhidos dentre cidadãos com mais de 35 e menos de 65 anos de idade, de notável saber jurídico e reputação ilibada (art. 101 da CF/88), e nomeados pelo Presidente da República, após aprovação da escolha pela maioria absoluta do Senado Federal". Extraído de: http://www.stf.jus.br/portal/cms/verTexto.asp?servico= sobreStfConhecaStfInstitucional. Acessado em 08 de julho de 2012.

${ }^{5}$ Argumentos e intelectuais que podem ser vistos no manifesto "Carta Pública ao Congresso Nacional - Todos têm direitos iguais na República Democrática”, de 30 de maio de 2006, entregue aos presidentes do Senado e da Câmara dos Deputados (vide: http:// www1.folha.uol.com.br/folha/educacao/ult305u18773.shtml), e no manifesto "Cento e Treze Cidadãos Anti-racistas Contra as Leis Raciais", de 30 de abril de 2008, entregue ao presidente do STF (vide: http://www1.folha.uol.com.br/folha/educacao/ult305u401519.shtml).

${ }^{6}$ Extraído de: http://www.stf.jus.br/arquivo/cms/noticiaNoticiaStf/anexo/ADPF186MMA.pdf. Acessado 21 de junho de 2012. 
Contudo, o reconhecimento da legalidade das ações afirmativas no Brasil para estudantes negros e indígenas não foi e não é condição suficiente para que o poder executivo federal execute essas políticas. Neste artigo, buscaremos demonstrar que tanto para a administração Fernando Henrique Cardoso (FHC), de orientação pró-mercado ou neoliberal, quanto para a administração Lula, de orientação pró-políticas sociais, a questão racial e/ou as desigualdades raciais (que afetam expressivamente a população negra), assim como as propostas de combate ao racismo, não foram prioridade em suas agendas. 0 presidente Fernando Henrique Cardoso, apesar inaugurar mudanças nos discursos oficiais brasileiros e nos marcos normativos sobre a questão racial, não apoiava aquelas políticas explicitamente. 0 presidente Lula, apesar de explicitar verbalmente o apoio a tais políticas e criar a Secretaria Especial de Políticas de Promoção da Igualdade Racial (SEPPIR) no seu primeiro ano de governo, não implementou nenhuma política de ação afirmativa para estudantes negros nas instituições de ensino público superior brasileiras.

Assim sendo, parte-se do entendimento de que independente de alinhamento ideológico, ou seja, quer sejam orientadas por práxis política neoliberal, como foi o governo de Fernando Henrique Cardoso, quer sejam balizadas por visões de mundo de centro-esquerda, como foi o governo Lula, as ações destinadas a enfrentar as desigualdades com fundamento racial ocupam um lugar marginal nos inúmeros projetos destinados a dar ensejo ao efetivo desenvolvimento do país. Desse modo, a preocupação deste artigo é apontar que, no Brasil, as políticas de ações afirmativas e as políticas de promoção da igualdade racial ainda não integram, como deveriam, um projeto de Estado que também deveria ter como prioridade a transposição do racismo. Para além disso, a discussão que aqui se apresenta procurará evidenciar que a intenção institucional em apoiar ou não as políticas de promoção da igualdade racial independe de coloração ou ideologia partidária, ainda que concepções inclinadas à direita sejam mais resistentes às mudanças nessa área, conforme a História recente do país vem demonstrando. 


\section{Políticas de Promoção da Igualdade Racial}

Mesmo que haja relação mútua entre as políticas de promoção da igualdade racial e as políticas de ação afirmativa, esses termos não são sinônimos. Em realidade podemos encontrar várias definições de ação afirmativa no Brasil, assim como algumas definições de políticas de promoção da igualdade racial. Mas para uma discussão inicial, assim como para os objetivos desse artigo, é preciso saber, conforme designaram as pesquisadoras Luciana de Barros Jaccoud e Nathalie Beghin (2002), que há pelos menos três tipos de políticas ou ações de combate ao racismo e às desigualdades raciais no Brasil: a) ações repressivas; b) ações valorizativas; e c) ações afirmativas:

as ações afirmativas e as políticas repressivas são entendidas (...) como aquelas que se orientam contra comportamento e conduta. As políticas repressivas visam combater o ato discriminatório - a discriminação direta usando a legislação criminal existente. Note-se que as ações afirmativas procuram combater a discriminação indireta, ou seja, aquela discriminação que não se manifesta explicitamente por atos discriminatórios, mas sim por meio de formas veladas de comportamento cujo resultado provoca a exclusão de caráter racial. As ações afirmativas têm como objetivo, assim, não o combate ao ato discriminatório (...), mas sim o combate ao resultado da discriminação, ou seja, o combate ao processo de alijamento de grupos raciais dos espaços valorizados da vida social. As políticas de ações afirmativas são medidas que buscam garantir a oportunidade de acesso dos grupos discriminados, ampliando sua participação em diferentes setores da vida econômica, política, institucional, cultural e social. Elas se caracterizam por serem medidas temporárias e (...) por dispensarem um tratamento diferenciado e favorável com vistas a reverter um quadro histórico de discriminação e exclusão. As ações valorizativas, por sua vez, são (...) entendidas como aquelas que têm por meta combater estereótipos negativos, historicamente construídos e consolidados na forma de preconceitos e racismo. Tais ações têm como objetivo reconhecer e valorizar a pluralidade étnica que marca a sociedade brasileira e valorizar a 
comunidade afro-brasileira, destacando tanto seu papel histórico como sua contribuição contemporânea à construção nacional. Nesse sentido, as políticas e as ações valorizativas possuem caráter permanente e não focalizado. Seu objetivo é atingir não somente a população racialmente discriminada - contribuindo para que ela possa reconhecer-se na história e na nação -, mas toda a população, permitindo-lhe identificar-se em sua diversidade étnica e cultural (JACCOUD e BEGHIN, 2002, p. 55-56).

Embora a citação seja longa, ela nos mostra uma classificação de ações contra o racismo extremamente importante para construirmos uma definição sintética de políticas de promoção da igualdade racial no Brasil. Essas políticas podem ser obtidas e até mesmo definidas por meio de todas as ações ou políticas públicas e/ou privadas, como as citadas acima, que visam a combater o racismo, o preconceito, a discriminação e as desigualdades raciais em todas as esferas da vida social.

Considerando que o Brasil é um país multirracial, esse combate não pode se limitar e ser feito somente por meio de ações repressivas, isto é, da proibição do racismo e da punição de sua prática, de acordo com a legislação vigente, mas deve ser feito também por meio de ações valorizativas, ou seja, da valorização dos grupos raciais e étnicos que são discriminados. Assim, se faz necessário ter também ações contra os preconceitos, estereótipos e estigmas de caráter racista, visando à valorização de todos os grupos raciais e étnicos brasileiros, especialmente negros e indígenas, como determina a Lei no $10.639 / 2003$, que foi alterada pela Lei no $11.645 / 2008^{7}$. Portanto, na busca da promoção da

\footnotetext{
${ }^{7}$ Esta lei estabelece que: "Art. 26-A. Nos estabelecimentos de ensino fundamental e de ensino médio, públicos e privados, torna-se obrigatório o estudo da história e cultura afro-brasileira e indígena. $\S 1^{\underline{0}} 0$ conteúdo programático a que se refere este artigo incluirá diversos aspectos da história e da cultura que caracterizam a formação da população brasileira, a partir desses dois grupos étnicos, tais como o estudo da história da África e dos africanos, a luta dos negros e dos povos indígenas no Brasil, a cultura negra e indígena brasileira e o negro e o índio na formação da sociedade nacional, resgatando as suas contribuições nas áreas social, econômica e política, pertinentes à
} 
igualdade racial não se pode propagar somente ações e imagens positivas da população branca, como historicamente fez e faz a visão de mundo eurocêntrica e hegemônica no ensino formal brasileiro em todos os seus níveis, do fundamental ao universitário (Cf. MUNANGA, 1999; SILVA, 2005).

Além disso, as políticas de promoção da igualdade racial também têm como objetivo promover a igualdade de oportunidade, de tratamento, assim como promover a inclusão (por meio de acesso e permanência diferenciados) dos grupos discriminados racialmente em áreas onde eles são sub-representados em função da discriminação que sofreram e sofrem em face da sua cor, raça ${ }^{8}$ e etnia. Ou seja, se faz necessário também a implementação de ações afirmativas.

Deve-se acrescentar também, apesar de estarmos discutindo especificamente a questão racial brasileira, que o combate ao racismo, para ser eficaz, não pode se limitar a políticas específicas (ou focalizadas) direcionadas aos grupos discriminados racialmente. É imprescindível haver políticas universais associadas e complementadas por políticas específicas, umas dando suporte às outras, visando a uma ressocialização coletiva da sociedade brasileira, mediante a qual não somente os grupos estigmatizados racialmente sejam protegidos contra a discriminação racial, mas os indivíduos que pertençam aos grupos raciais que

história do Brasil. § $2^{\underline{0}}$ Os conteúdos referentes à história e cultura afro-brasileira e dos povos indígenas brasileiros serão ministrados no âmbito de todo o currículo escolar, em especial nas áreas de educação artística e de literatura e história brasileiras". Na Lei no 10.639, de 09 de janeiro de 2003, em virtude da sua alteração pela lei supracitada, restou o seguinte artigo: "Art. 79-B. 0 calendário escolar incluirá o dia 20 de novembro como 'Dia Nacional da Consciência Negra'”.

${ }^{8}$ Conforme Bernardino, Santos e Silvério (2009, p. 215), "Para que não haja dúvidas ou mal-entendidos sobre o conceito de raça que estamos utilizando, ressaltamos que a raça não existe cientificamente, bem como não é uma realidade natural. Raça é uma construção social e não um conceito biológico. Desse modo, enfatizamos que, embora a raça não exista cientificamente, ela existe socialmente". 
se autodeclaram e/ou se sentem superiores, e que discriminam outros grupos raciais, sejam reeducados para que não o façam. Ou seja, provavelmente não haverá promoção da igualdade racial em sentido amplo se, simultaneamente, não houver políticas universalistas de boa qualidade, especialmente nas áreas de educação, cultura, emprego/salário/trabalho, saúde, segurança, previdência e assistência sociais, habitação, entre outras áreas.

Portanto, para que as políticas de promoção da igualdade racial tenham potencial transformador contra a prática do racismo, não se pode abrir mão de políticas universais associadas a elas, uma vez que todas elas são fundamentais para o desenvolvimento do potencial humano de cada indivíduo, visto que todas essas políticas em interação possibilitam, de fato, a construção de sociedades mais igualitárias, baseadas na igualdade de oportunidade/acesso e de tratamento, onde os indivíduos possam escolher e/ou ser donos dos seus próprios destinos.

Como se vê, as políticas de promoção da igualdade racial não se confundem nem se limitam às políticas de ações afirmativas. As primeiras são algo mais amplo e mais complexo que essas últimas, até porque as ações afirmativas são um tipo de política de promoção da igualdade racial. Em outras palavras, são necessários vários tipos de políticas públicas e/ou sociais, e até mesmo privadas, articuladas e em interação, e sem prescindir das políticas universais, para se promover a igualdade racial e se combater a prática do racismo.

Desse modo, a definição de políticas de promoção da igualdade racial é abrangente, visto que requer a articulação e interação de várias ações e/ou políticas, tais como ações repressivas, ações valorizativas, ações afirmativas, políticas universais e políticas específicas (ou focalizadas). Isso ocorre, entre outros fatores, porque, de um lado, o racismo é dinâmico, se renova e se reestrutura de acordo com a evolução da sociedade e das conjunturas históricas (MUNANGA, 1994, p. 178) e, de outro lado, a luta 
contra o racismo também não é estática e, desse modo, as formas de reação e combate a ele são múltiplas, requerendo não apenas uma, mas várias ações e políticas públicas e/ou sociais e privadas.

\section{0 surgimento das propostas de ações afirmativas no Brasil: breve histórico}

As parcas políticas de ações afirmativas que foram e/ou estão sendo implementadas no Brasil nos últimos quinze anos, não são obra da boa vontade dos governos ${ }^{9}$ ou do Estado brasileiro, cuja trajetória vertical vem de cima (do Estado/governo/elites dirigentes brasileiras) para baixo (população negra discriminada), como alguns intelectuais conservadores brasileiros costumeiramente afirmam ${ }^{10}$. Essas políticas estão em acordo com o princípio esboçado pelo pesquisador Pedro Demo (2003), para quem é fundamental que as chamadas políticas focalizadas sejam demandadas pelos seus beneficiários, a fim de que sejam efetivadas adequadamente e alcancem êxito.

Neste sentido, devemos frisar que na primeira metade da década de 1940 os movimentos negros brasileiros respondiam ao princípio assinalado por Demo, por meio da reivindicação de políticas de ações afirmativas para a população afro-brasileira. As proposições do Manifesto às Forças Políticas da Nação Brasileira e do Manifesto à Nação Brasileira são cristalinas quanto a isso. 0 primeiro Manifesto foi lançado pela "Convenção Política do Negro”, realizada em 1945, no Rio de Janeiro. 0 segundo foi lançado na "Convenção Nacional do Negro Brasileiro", realizada em

\footnotetext{
${ }^{9}$ Quer sejam eles de orientação neoliberal ou de orientação pró-Estado de bem estar social.

${ }^{10}$ Vide, por exemplo, Yvone Maggie (2005), Peter Fry (2005) e Maggie e Fry (2004).
} 
1945 (em São Paulo) e em 1946 (no Rio de Janeiro) ${ }^{11}$. Conforme líder negro Abdias Nascimento, as organizações afro-brasileiras já estavam, naquela época, propondo aos partidos que a questão racial deveria constar em seus programas políticas. "Além disso, mais uma vez, constatamos que, desde antes da Constituinte de 1946, o movimento organizado afro-brasileiro já pleiteava a adoção de políticas afirmativas compensatórias, neste caso metas de participação dos negros no processo eleitoral por meio de cotas" (NASCIMENTO e NASCIMENTO, 2004, p. 122). Portanto, não sem sentido que naqueles manifestos, constam, respectivamente:

... que faça valer esse apoio assegurando à Convenção Política do Negro Brasileiro, por sua indicação, o seguinte: 'a) nas Chapas [dos partidos] para a representação federal dos Estados do Ceará, Paraíba, Pernambuco, Distrito Federal, Rio de Janeiro, uma cadeira [para candidato negro]; nas dos Estados da Bahia e Rio Grande do Sul, duas cadeiras; nas dos Estados de Minas Gerais e São Paulo, três cadeiras; b) nas Assembleias Legislativas de cada Estado, em proporção a ser determinada no momento oportuno, bem assim como nas Câmaras Municipais.

Enquanto não for tornado gratuito o ensino em todos os graus, sejam admitidos brasileiros negros, como pensionistas do Estado, em todos os estabelecimentos particulares e oficiais de ensino secundário e superior do país, inclusive nos estabelecimentos militares.

Como se observa nas citações acima, os movimentos negros brasileiros já postulavam políticas de ações afirmativas antes mesmo de estas converterem-se em plataforma política nos Estados Unidos da América. Para torná-las exequíveis, esses movimentos

${ }^{11}$ A Convenção Nacional do Negro foi, efetivamente, a continuação e desdobramento da Convenção Política do Negro, organizada por militantes do Teatro Experimental do Negro (TEN) e da União Negra Brasileira. Esta última foi realizada em 28 de setembro de 1945, no Rio de Janeiro. Segundo Nascimento e Nascimento, a Convenção Nacional do Negro "teve sua primeira reunião nacional em São Paulo em 1945, e a segunda no Rio de Janeiro em 1946, constituindo-se num fórum permanente de reunião em ambas as cidades" (NASCIMENTO E NASCIMENTO, 2004, p.123). 
propunham duas técnicas de implementação: a) por meio de um sistema de cotas, como a reserva de vagas para candidatos negros nas legendas partidárias; e b) por meio da concessão bolsas de estudo pelo Estado brasileiro aos estudantes negros, a fim de ingressarem no ensino secundário e nas universidades públicas e privadas.

Deve-se enfatizar que o pleito dos movimentos negros por ações afirmativas no Brasil, embora sem sucesso na referida época, teve continuidade no decurso da história. Alguns exemplos mostram-se instrutivos: Em 1950, o Teatro Experimental do Negro (TEN) organizou o " $1{ }^{\circ}$ Congresso do Negro Brasileiro". Entre as propostas da declaração final desse congresso, constava "a inclusão de homens de cor nas listas de candidatos das agremiações partidárias, a fim de desenvolver a sua capacidade política e formar líderes esclarecidos, que possam traduzir, em formas ajustadas às tradições nacionais, as reivindicações das massas de cor" (I Congresso do Negro Brasileiro apud NASCIMENTO, 1982, p. 401-402). Ou seja, novamente é requerida uma política de sistema de cotas, isto é, de reserva de vagas para candidatos negros nas legendas partidárias brasileiras.

Em 1983, o líder negro e então deputado federal Abdias Nascimento $^{12}$ submeteu à apreciação do Congresso Nacional bra-

${ }^{12}$ Fundador do Teatro Experimental do Negro (TEN), Abdias Nascimento era o legítimo e legal representante dos movimentos sociais negros no Congresso Nacional brasileiro. O seu mandato parlamentar era de fato e de direito da, pela e para a população negra. Esse ativista não era apenas um deputado federal que tinha uma base eleitoral composta majoritariamente por negros ou um representante generoso dos movimentos negros no Congresso Nacional. Ele era não só "o mais importante ativista afro-brasileiro neste século [XX]” (MEDEIROS, 1998, p. 95), mas também era visto como a intervenção direta dos movimentos negros no parlamento brasileiro. A propósito, em março de 2004, aos 90 anos de idade, Abdias Nascimento foi reconhecido oficialmente pelo governo brasileiro, por meio de homenagem do então presidente Luiz Inácio Lula da Silva, como "maior expoente brasileiro na luta intransigente pelos direitos dos negros no combate à discriminação, ao preconceito e ao racismo" (SEMOG e NASCIMENTO, 2006, p. 115). Abdias Nascimento faleceu aos 97 anos de idade, em 24 de maio de 2011. 
sileiro propostas concretas de ações afirmativas para cidadãos negros nas esferas da educação, emprego/trabalho, entre outras áreas, por meio do Projeto de Lei (PL) $\mathrm{n}^{\circ} 1.332$. Esse projeto foi apresentado na Sala de Sessões da Câmara dos Deputados, no dia 7 de junho de 1983. Ele dispunha "sobre ação compensatória visando à implementação do princípio da isonomia social do negro, em relação aos demais segmentos étnicos da população brasileira, conforme direito assegurado pelo art. $153, \S 1^{\circ} \mathrm{da}$ Constituição da República" (NASCIMENTO, 1985, p. 61). 0 artigo sétimo desse PL refere-se especificamente à área de educação, onde se propõe: "Serão concedidas a estudantes negros bolsas de estudo de caráter compensatório. $\S 1$ 으 - Serão destinadas a estudantes negros $40 \%$ (quarenta por cento) das bolsas de estudo concedidas pelo Ministério da Educação e Cultura e pelas Secretarias de Educação Estaduais e Municipais em todos os níveis (primário, secundário, superior e de pós-graduação)”. A exemplo das demais propostas de ações afirmativas reivindicadas pelos movimentos negros, vistas anteriormente, esse PL não logrou êxito. Ele tramitou na Câmara por aproximadamente cinco anos e dez meses. Ao chegar à Mesa Diretora da Câmara dos Deputados em 5 de abril de 1989, foi arquivado conforme pode ser observado no sítio da Câmara dos Deputados ${ }^{13}$.

O que se depreende dos parágrafos anteriores é que, historicamente, as reivindicações por políticas de ações afirmativas para a população negra no Brasil têm sido vocalizadas pelos movimentos negros. Irrevogavelmente, resulta dessa demanda, a aplicação de algumas modalidades de ações afirmativas na aurora do século XXI, em diversas universidades públicas brasileiras. Reafirmamos, portanto, que esse estágio de inclusão da população negra, mormente na educação superior, não é fruto das politicas gestadas pelo Estado brasileiro, menos ainda configura-se como uma suposta cópia de políticas públicas estadunidenses

${ }^{13}$ Extraído de: http:/www.cama.gov.br/sileg/Prop_Deatalhe.asp?id=190742. Acessado em 21 de março de 2007. 
impermeáveis ao contexto brasileiro, conforme afirmam alguns intelectuais da área de estudos e pesquisas sobre relações raciais no Brasil, como Yvonne Maggie (2005), Peter Fry (2005), Yvonne Maggie e Peter Fry (2004).

Contudo, a entrada efetiva das discussões sobre as políticas de ação afirmativa para a população negra no escopo das demandas brasileiras só ocorreria no início da década de 2000. Um dos antecedentes para que isso acontecesse foi a realização da "Marcha Zumbi dos Palmares contra o racismo, pela cidadania e a vida", em 20 de novembro de 1995, em Brasília, capital do Brasil. Este fato foi responsável por levar a discussão da questão racial brasileira, cada vez mais, para as fronteiras de atuação do Estado.

Organizada para reafirmar a luta dos afro-brasileiros contra o racismo e as desigualdades raciais e exigir, em caráter emergencial, políticas públicas para a população negra, a Marcha Zumbi dos Palmares contou com a presença de mais de trinta mil participantes. A importância política dessa mobilização pode ser observada e dimensionada sob várias perspectivas. Uma delas é a recepção das lideranças dos movimentos negros pelo então presidente da República, Fernando Henrique Cardoso, no Palácio do Planalto, sede do poder executivo brasileiro.

De maneira contundente, as vozes presentes na Marcha renovaram as denúncias do racismo e da discriminação racial, pressionando o governo brasileiro a tomar providências em tempo hábil. Além disso, as altissonantes denúncias foram convertidas em um programa de ação entregue ao chefe de Estado brasileiro: o Programa de Superação do Racismo e da Desigualdade Racial, que continha várias propostas de combate ao racismo. Em virtude do espaço que temos para escrever este artigo, citaremos apenas as propostas da área de educação. Nessa área havia tanto propostas de políticas universalistas como de ações valorizativas e de ações afirmativas, como se pode ver abaixo. 
- Recuperação, fortalecimento e ampliação da escola pública, garantia de boa qualidade.

- Implementação da Convenção Sobre Eliminação da Discriminação Racial no Ensino.

- Monitoramento dos livros didáticos, manuais escolares e programas educativos controlados pela União.

- Desenvolvimento de programas permanentes de treinamento de professores e educadores que os habilite a tratar adequadamente com a diversidade racial, identificar as práticas discriminatórias presentes na escola e o impacto destas na evasão e repetência das crianças negras.

- Desenvolvimento de programa educacional de emergência para a eliminação do analfabetismo. Concessão de bolsas remuneradas para adolescentes negros de baixa renda para o acesso e conclusão do primeiro e segundo graus [atuais ensinos fundamental e médio, respectivamente].

- Desenvolvimento de ações afirmativas para acesso dos negros aos cursos profissionalizantes, à universidade e às áreas de tecnologia de ponta (EXECUTIVA NACIONAL DA MARCHA ZUMBI, 1996, p. 24 e 25).

Assim, a Marcha Zumbi dos Palmares serviu também para dar visibilidade às propostas desenhadas para a área de educação, ordenadas segundo os princípios das políticas universalistas, valorizativas e de ação afirmativa. Essa arquitetura política dos projetos formulados no âmbito da educação atribui aos movimentos negros uma visão sistêmica ou global sobre o assunto. Políticas de ação afirmativa, conjugadas com políticas valorizativas da população negra que, por sua vez, devem caminhar em paralelo com as políticas universalistas, são um dos trajetos possíveis para que as distâncias entre as populações branca, negra (preta e parda) e indígena, mormente no ensino superior, possam ser mais eficazmente eliminadas. Em face do exposto, pode-se dizer, sem exageros, que a "Marcha Zumbi dos Palmares" converteu-se em um divisor de águas no combate ao racismo. Com um escopo de propostas desenhado pelos movimen- 
tos negros brasileiros, essa mobilização deixou descobertos os problemas que incidem sobre a população negra, fazendo com que as reivindicações históricas desses movimentos pudessem ser acolhidas nas esferas de decisão, principalmente por alguns parlamentares negros.

\section{Ações Afirmativas no Governo Fernando H enrique Cardoso?}

Apesar de acolher as demandas supracitadas, o presidente Fernando Henrique Cardoso (FHC) não levou a efeito iniciativas concretas que fossem capazes de incluir a população negra no ensino superior público: nenhum projeto de lei de ações afirmativas para estudantes negros ingressarem no ensino público superior brasileiro foi apresentado, pela administração desse presidente, ao Congresso Nacional brasileiro. Nenhuma ação mais arrojada surgiu no horizonte do possível, embora, para alguns autores brasileiros, as políticas de ação afirmativa para a população afro-brasileira tenham sido iniciadas na administração FHC (1995 a 2002). Mais do que isto, para a pesquisadora Marilene de Paula (2010, p. 34), o governo FHC "teve papel destacado" na discussão e execução dessas políticas. Segundo essa pesquisadora,

Minha investigação persegue a ideia de que a partir de 1995, apesar de todos os contratempos, dos debates acalorados na mídia e na sociedade em geral, políticas públicas específicas, ou assim chamadas ações afirmativas para a população negra, foram e estão sendo implementadas. Apesar da polêmica em torno das cotas raciais nas universidades, uma das ações afirmativas mais contestadas, o governo brasileiro tem reiteradamente reconhecido a necessidade de uma política diferencialista para esse grupo historicamente discriminado, política e socialmente. Iniciadas no governo Fernando Henrique e ampliadas no governo Lula, inúmeras iniciativas estão sendo realizadas (PAULA, 2010, p. 14). 
Contudo, como se verá mais à frente, o presidente Fernando Henrique Cardoso, comandante de uma administração neoliberal (Cf. MATTEI e MAGALHÃES, 2011; FALEIROS, 2004; e SALLUM JR. 1999), sustentada por "um governo de coalizão majoritário de centro-direita" (Cf. FIGUEIREDO, LIMONGI e VALENTE, 1999, p. 50), era contra políticas de ações afirmativas para a população negra, especialmente no ensino superior.

A responsabilidade por algumas iniciativas com consequência política ficou principalmente a cargo de alguns parlamentares negros, como Benedita da Silva (PT/RJ), Paulo Paim (PT/RS), Luiz Alberto (PT/BA), Vicentinho (PT/SP), Carlos Santana (PT/ $\mathrm{RJ})$, Janete Pietá (PT/SP) e Evandro Milhomem (PC do B/AP). Todos esses parlamentares, filiados a partidos considerados de esquerda, eram herdeiros do protagonismo de Abdias Nascimento no Congresso Nacional, assim como eram, em geral, articulados com ou representantes dos movimentos sociais negros. Em virtude disso, encaminharam ou apresentaram propostas de políticas de ações afirmativas que atendiam a algumas das reivindicações desses movimentos. Por exemplo, a então senadora Benedita da Silva, do Partido dos Trabalhadores do Estado do Rio de Janeiro, articulada com os movimentos negros, apresentou, entre outros, o Projeto de Lei no 14 , de 1995, que instituía a cota mínima de $10 \%$ de vagas em instituições de ensino superior públicas e particulares de âmbito federal, estadual e municipal, para os setores étnico-raciais (CARDOSO, 1998, p. 81). Sem apoio expressivo do governo FHC, que tinha a maioria política no Congresso Brasileiro, essa proposta não foi aprovada.

Por outro lado, não devemos desconhecer que se as medidas do presidente Fernando Henrique mostraram-se insuficientes em âmbito mais efetivo, elas ganharam sentido no plano simbólico, instituindo-se como indicações de possibilidades para a superação do racismo. Exemplo disso foi a criação, por meio de decreto de 20 de novembro de 1995, do Grupo de Trabalho Interministerial para a Valorização da População Negra (GTI), instituído, no 
entanto, tardiamente, em 27 de fevereiro de 1996. 0 GTI tinha "como expectativa, ao longo deste governo [FHC], inscrever definitivamente a questão do negro na agenda nacional. Isso significará conceder à questão racial do negro brasileiro a importância que lhe tem sido negada" (GTI In Brasil, 1998, p. 39), mas reduziu-se a uma instituição de articulação intragovernamental, sem caráter executivo.

Esse Grupo de Trabalho Interministerial ficou responsável por estabelecer uma interlocução com os diversos ministérios e entes estatais, com vistas à promoção da igualdade racial por meio da discussão, elaboração e execução de políticas públicas direcionadas à população negra. Sem recursos próprios, com um corpo técnico insuficiente para a realização de todas as suas funções e com infraestrutura inadequada, o GTI ficou aquém das possibilidades inicialmente delineadas.

Além do GTI, o governo FHC instituiu, também por meio de decreto, de 20 de março de 1996, o Grupo de Trabalho para a Eliminação da Discriminação no Emprego e na Ocupação (GTEDEO). Com raízes fincadas no Ministério do Trabalho, este grupo tinha como finalidade definir programas de ações que visassem ao combate à discriminação no emprego e na ocupação. Como o GTI, o que fundamenta a criação do GTEDEO não é a boa vontade ou a consciência do presidente da República, mas as reivindicações dos movimentos negros pela promoção da igualdade racial, que pressionaram o governo durante a "Marcha Zumbi dos Palmares".

A propósito, o surgimento do GTEDEO foi motivado pela denúncia do não cumprimento da Convenção 111 da Organização Internacional do Trabalho (OIT), ${ }^{14}$ protagonizada pelo Sindicato

${ }^{14}$ Denominada “Convenção sobre a discriminação (emprego e profissão, 1958)", a Convenção no 111 da Organização Internacional do Trabalho (OIT), no seu art.1ำ estabelece que "Para os fins da presente convenção o termo 'discriminação' compreende: a) Toda 
dos Bancários de Florianópolis e a Central Única dos Trabalhadores (CUT), em 1992. 0 Centro de Estudos das Relações do Trabalho e Desigualdade (CEERT), na qualidade de representante legítimo dos movimentos negros, coagiu o governo brasileiro a tomar as medidas cabíveis.

A despeito da atuação restrita, esses grupos de trabalho suscitaram tensões na agenda governamental, abrindo brechas para que a questão racial fosse paulatinamente incluída no interior da estrutura burocrático-administrativa brasileira (ministérios, autarquias, fundações, universidades, entre outros).

Algumas exceções, a exemplo do seminário internacional Multiculturalismo e racismo: o papel da ação afirmativa nos Estados democráticos contemporâneos, conseguiram debater de forma consequente o problema das relações raciais brasileiras no âmbito governamental e avaliar a viabilidade da formulação de políticas públicas de combate à discriminação racial, com ênfase nas políticas de ações afirmativas. Este seminário, que aconteceu em julho de 1996, foi organizado pelo Departamento dos Direitos Humanos, da Secretaria dos Direitos da Cidadania do Ministério da Justiça, na Universidade de Brasília (UnB). Vale ressaltar que, assim como a criação do GTI, este seminário foi uma das respostas do governo FHC à "Marcha Zumbi dos Palmares contra o

distinção, exclusão ou preferência fundada na raça, cor, sexo, religião, opinião política, ascendência nacional ou origem social, que tenha por efeito destruir ou alterar a igualdade de oportunidade ou de tratamento em matéria de emprego ou profissão". 0 art. $2^{\text {o }}$ estabelece que "Qualquer Membro para o qual a presente convenção se encontre em vigor compromete-se a formular e aplicar uma política nacional que tenha por fim promover, por métodos adequados às circunstâncias e aos usos nacionais, a igualdade de oportunidades e de tratamento em matéria de emprego e profissão, com o objetivo de eliminar toda discriminação nessa matéria" (Convenção 111 da OIT apud SÜSSEKING, 1994, p. 244). Percebe-se assim, que o objetivo dessa norma internacional é evitar as discriminações e promover a igualdade de oportunidade e de tratamento no trabalho. Esta convenção foi aprovada na $42^{\text {a }}$ reunião da Conferência Internacional do Trabalho, no ano de 1958, em Genebra, e ratificada pelo Brasil em 26 de novembro de 1965 (SÜSSEKIND, 1994, p. 243). 
racismo, pela cidadania e a vida". Mais ainda, foi no seu transcorrer que o presidente Fernando Henrique Cardoso afirmou que o Brasil é um país que discrimina racialmente a população negra e exortou todos os presentes a serem proativos no combate ao racismo. Foi a primeira vez na história do país que um chefe do Estado brasileiro declarou pública e oficialmente que havia discriminação racial ou racismo contra a população negra. As palavras do presidente exigem a tomada de providências:

Nós, no Brasil, de fato convivemos com a discriminação e convivemos com o preconceito (...), a discriminação parece se consolidar como alguma coisa que se repete, que se reproduz. Não se pode esmorecer na hipocrisia e dizer que o nosso jeito não é esse. Não, o nosso jeito está errado mesmo, há uma repetição de discriminações e há a inaceitabilidade do preconceito. Isso tem de ser desmascarado, tem de ser, realmente, contra-atacado, não só verbalmente, como também em termos de mecanismos e processos que possam levar a uma transformação, no sentido de uma relação mais democrática, entre as raças, entre os grupos sociais e entre as classes (CARDOSO, 1997, p. 14-16).

Ao reconhecer oficial e publicamente que há desigualdade racial no Brasil, como consequência do racismo, o presidente Fernando Henrique Cardoso nos legou um fato sócio-político sem precedentes na nossa história. Essa declaração não se deve somente a uma "convicção antiga" e ao compromisso intelectual ${ }^{15}$ que o presidente tinha com a superação do racismo (já que foi pesquisador na área), mas deve ser atribuída às pressões internas e ex-

${ }^{15}$ Conforme afirmou o ex-presidente Fernando Henrique Cardoso: "Sou comprometido pessoalmente com os estudos da questão negra no Brasil. Escrevi dois livros sobre a matéria na época em que se mantinha a idéia de que, no Brasil, não havia um problema negro e que não havia discriminação racial. Com o professor Florestan Fernandes e com Octavio Ianni, sob a inspiração de Bastide, fizemos pesquisas que mostraram o oposto: havia preconceito, havia discriminação. E para que pudesse se concretizar o ideal de democratização do Brasil implicaria que os que lutam pela democracia e pela liberdade, assumissem também a luta em favor da igualdade racial. Por ser convicção antiga creio firmemente nisso (CARDOSO In Brasil, 1998, p. 7). 
ternas que punham em cheque as supostas relações harmoniosas entre os segmentos étnico-raciais (negros - pretos e pardos -, brancos, indígenas e amarelos) em face das assimetrias, cujo fundamento no racismo apartava (e ainda continua separando desigualmente) os diferentes grupos.

Cada vez mais fragilizado, o mito da democracia racial brasilei$\mathrm{ra}^{16}$ não mais era visto como algo consensual por estudiosos e analistas estrangeiros empenhados em deslindar a dinâmica racial reinante no Brasil, conforme afirmou o historiador estadunidense Thomas E. Skidmore (1992, p.55). Internamente, a maturidade das organizações negras, a produção incessante de documentos clamando não somente por igualdade formal, mas também de fato e por inclusão, fizeram o governo do presidente FHC reconhecer a força estruturante do racismo e, assim, abrir espaço para a discussão de políticas afirmativas para a população negra (Cf. SANTOS, 2006).

Além dessas ações governamentais e mudanças no tom e conteúdo discursivo do presidente, credita-se aos movimentos negros a instituição de marcos normativos: o Programa Nacional de Direitos Humanos (PNDH), criado por força do decreto $\mathrm{n}^{\mathrm{o}}$ 1.904 , de 13 de maio de 1996, dá prova disso. No prefácio do documento, Fernando Henrique Cardoso afirmava que "não há como conciliar democracia com as sérias injustiças sociais, as formas variadas de exclusão e as violações reiteradas aos direitos humanos que ocorrem em nosso país" (CARDOSO apud BRASIL, 1996, p. 05).

Assim sendo, no PNDH de 1996, o governo brasileiro propõe uma série de ações governamentais visando à superação de vá-

\footnotetext{
${ }^{16}$ Segundo Carlos Hasenbalg, "a noção de mito para qualificar a 'democracia racial' é aqui usada no sentido de ilusão ou engano e destina-se a apontar para a distância entre representação e realidade, a existência de preconceito, discriminação e desigualdades raciais e sua negação no plano discursivo" (HASENBALG, 1996, p. 237). Noção que endossamos.
} 
rias injustiças sociais que há na sociedade brasileira. Além disso, o Presidente Fernando Henrique Cardoso lança esse programa em um 13 de maio, data que para os movimentos sociais negros é considerada o "Dia Nacional de Denúncia contra o Racismo". E no que diz respeito às injustiças contra os negros, "a presunção fundadora dessas propostas [do PNDH] é o reconhecimento da existência da discriminação [racial]", como afirmou o pesquisador Jorge da Silva (2001, p. 39).

Pela primeira vez na história do Brasil aparece de forma explícita a inserção do tema das políticas de ações afirmativas para a população negra em um documento oficial. Muito do que constava no PNDH alusivo às políticas de ações afirmativas era praticamente cópia ou ratificação das propostas do Programa de Superação do Racismo e da Desigualdade Racial, elaborado pelos movimentos negros, como a proposta de "Desenvolver ações afirmativas para o acesso dos negros aos cursos profissionalizantes, à universidade e às áreas de tecnologia de ponta" (BRASIL, 1996, p. 31).

Essa absorção demonstra o quanto o governo brasileiro mudou em relação às demandas dos movimentos negros, incorporando-as discursivamente no escopo de suas principais ações. Todavia, apesar de realizar algumas mudanças em termos de discurso e de legislação antirracismo, bem como de passar de uma posição de "política de não ter política"17 para uma de "política de ter política" ${ }^{18}$ no campo das relações raciais (Cf. SILVA 2001), o governo FHC ficou mais para o plano simbólico que para o plano das mudanças e práticas concretas, visto que esta "política de ter política” para a inclusão dos negros em áreas de prestígio, poder e mando, por meio de ações afirmativas, foi mais protocolar e formal que substantiva (Cf. SANTOS, 2007).

\footnotetext{
${ }^{17} \mathrm{Ou}$ seja, de neutralidade estatal com relação ao reconhecimento do racismo contra os negros e das desigualdades raciais entre negros e brancos no Brasil.

${ }^{18}$ No sentido de reconhecer a discriminação contra os negros e supostamente intervir politicamente visando a combatê-la.
} 
Contudo, essas mudanças no plano discursivo do governo FHC, como a criação de alguns grupos de trabalho, como o GTI e o GTDEO e a normatização do sistema cotas, por meio de portarias, em três ministérios desse governo, levou a pesquisadora Marilene de Paula (2010) a concluir que houve implementação de políticas de ações afirmativas na administração FHC. Segundo essa pesquisadora,

Em pesquisa realizada por Luciana Jaccoud e Nathalie Beghin (2002) sobre medidas e ações em nível federal entre os anos 1995 e 2002 foram identificados 40 programas e ações em instituições governamentais, tanto no Executivo quanto no Judiciário. (...) na Administração Pública Federal, criação do Programa Nacional de Ações Afirmativas [PNAA] vinculado ao preenchimento de cargos de direção - DAS com metas de participação de $20 \%$ de afro-descendentes. (...) Os Ministérios do Desenvolvimento Agrário [MDA], das Relações Exteriores, da Justiça e da Cultura, foram os que mais criaram políticas nessa área (PAULA, 2010, p. 75-76).

Contudo, contraditoriamente, essa mesma pesquisadora reconhece que não houve, concretamente, execução de políticas de ações afirmativas na maioria das instituições que anunciaram tais políticas. É dela a afirmação de que "no caso do MDA não encontrei registros de que a reserva de vagas estabelecida pela referida portaria tenha sido efetivamente implementada" (PAULA, 2010, p. 85). Do mesmo modo, ela afirma que "o PNAA não pôde ser implementado, pois não tinha regulamentação específica” (PAULA, 2010, p. 96).

Em realidade, na administração federal aqui em análise foram implementadas apenas duas políticas de ações afirmativas focadas na população afro-brasileira, mas somente no último ano de exercício do governo Fernando Henrique (Cf. SILVA et. al., 2009). Ambas eram frágeis, sem garantias de que os afro-brasileiros pudessem lograr sucesso, visto que a dinâmica de implementação pautava-se na concessão de bolsa de estudo para cursos 
preparatórios com vistas ao ingresso em concursos na administração pública e no vestibular.

A primeira ação foi implementada pelo Ministério das Relações Exteriores (MRE). Foi criado, em março de 2002, o "Programa Bolsa-Prêmio de Vocação para a Diplomacia", que atualmente oferece 30 bolsas-auxílio (bolsa de estudo), por ano, no valor de $R \$ 25.000,00$, para custear a preparação de candidatos negros ao concurso de admissão à carreira de diplomata. Essa ação teve continuidade no governo do presidente Lula, alcançando maior abrangência, uma vez que no governo FHC eram ofertadas apenas 20 bolsas-auxílio, no valor de $\mathrm{R} \$ 15.000,00$ cada (Cf. PAULA, 2010). Segundo Silva et. al. (2009, p. 51), entre 2002 e 2007 foram concedidas 134 bolsas a candidatos negros. Nesse período, onze ex-bolsistas foram aprovados no Concurso de Admissão à Carreira de Diplomata (CACD) e foram admitidos no MRE.

Tal resultado, considerado abaixo das expectativas, é um forte indício da fragilidade dessa política de estímulo à entrada de candidatos negros na carreira diplomática brasileira por meio da bolsa-auxílio. Sem uma política de inclusão mais consequente, como um sistema de reserva de vagas, não há garantias de que uma quantidade razoável de afro-brasileiros terá êxito de fazer parte do corpo diplomático brasileiro.

A segunda ação afirmativa implementada na gestão de Fernando Henrique foi direcionada para a educação, com o "Programa Diversidade na Universidade", no âmbito do Ministério da Educação (MEC), por meio da Lei no 10.558 , de 13 de novembro de 2002. Sua finalidade manifesta era "implementar e avaliar estratégias para a promoção do acesso ao ensino superior de pessoas pertencentes a grupos socialmente desfavorecidos, especialmente dos afrodescendentes e dos indígenas brasileiros". Por meio desse programa foram concedidas bolsas de estudo para estudantes de baixa renda e/ou afro-brasileiros matriculados 
em cursos pré-vestibulares populares, os chamados pré-vestibulares para negros e carentes (PVNC) ${ }^{19}$.

Deve-se destacar alguns fatos em relação ao programa citado acima. Primeiro, esses cursos são inegavelmente precários, o que não possibilitava uma preparação adequada dos seus alunos para o vestibular. Em geral são cursos preparatórios não competitivos quando comparados com os cursos pré-vestibular das grandes redes de ensino privadas. Esse dado dificilmente favorece para que alunos negros e/ou carentes desses cursos populares atinjam o objetivo de ingressar nas universidades públicas brasileiras, que são as melhores do país. Outra questão deve ser posta em relevo: apesar do "Programa Diversidade na Universidade" ter sido criado no governo FHC, ele somente começou a ser efetivado na administração Lula, uma vez que a lei que o criou é de novembro de 2002, quando faltava apenas um mês para o fim da era FHC.

Orientado pela preferência e defesa dos PVNCs pela professora Yvonne Maggie (2001), em relação ao sistema de cotas, o ministro da educação do governo FHC, Paulo Renato Souza ${ }^{20}$, propôs

\footnotetext{
${ }^{19}$ Segundo o pesquisador Renato Emerson dos Santos, o PVNC é "um movimento social de corte racialista (...). O PVNC é uma rede de pré-vestibulares populares, surgida na Baixada Fluminense, nos anos 90, que chegou a congregar, no final daquela década [1990], quase 90 núcleos na Região Metropolitana do Rio de Janeiro. 0 movimento de pré-vestibulares, que surgiu como desdobramento do trabalho do PVNC, atualmente comporta milhares de cursos em todo o Brasil. Outras redes foram criadas e se nacionalizaram, como a Educafro (Educação e Cidadania para os Afro-Descendentes e Carentes, que atua nos estados do Rio de Janeiro, São Paulo, Minas Gerais e Espírito Santo, com mais de 190 núcleos e quase 10.000 alunos) e o Movimento dos Sem Universidade (MSU), que está estruturado em 10 estados (Bahia, Distrito Federal, Espírito Santo, Maranhão, Minas Gerais, Paraná, São Paulo, Rio Grande do Norte, Rio de Janeiro e Tocantins, são citados em sua página na internet), além de milhares de núcleos que atuam 'isoladamente' por todo o país" (SANTOS, 2005, p. 231-232).

${ }^{20}$ Esse ex-ministro foi uma das autoridades do primeiro escalão do governo FHC que mais se opuseram ao sistema de cotas para estudantes negros ingressarem no ensino público superior. Ele foi também uma das autoridades que mais publicaram artigos contrários ao sistema de cotas, para estudantes negros, no caderno "Tendências/Debates", do jornal "Folha
} 
como alternativa, e esse governo aprovou, o "Programa Diversidade na Universidade". Portanto, ao que tudo indica, este programa foi uma tentativa de retirar a pressão popular, especialmente dos movimentos negros, para que o governo FHC implementasse alguma política de ação afirmativa mais consequente, como o sistema de cotas, com a finalidade de incluir os estudantes negros no ensino público superior. Segundo o pesquisador Adailton Silva e outros, esse "programa foi uma alternativa ao desenvolvimento de cotas [raciais] no país e foi adotado em resposta às crescentes pressões em prol do desenvolvimento de políticas de ação afirmativa no ensino superior" (SILVA et. al., 2009, p. 37).

Em realidade, apesar de o ex-presidente FHC afirmar que tinha uma "convicção antiga" contra as injustiças raciais, ele não avançou na proposição de ações voltadas para a promoção da igualdade racial na esfera da educação superior pública ou em qualquer outra área. Ao contrário do que noticiou a imprensa brasileira durante a Conferência Mundial contra o Racismo, Homofobia, Xenofobia e tolerâncias correlatas, realizada em 2001, a gestão de FHC não levou a cabo a efetivação das políticas de cotas para ingresso de estudantes negros nas universidades públicas brasileiras. 0 tom vacilante da entrevista que o ex-presidente concedeu ao jornalista e escritor Roberto Pompeu de Toledo dá a justa medida do posicionamento governamental quanto à materialização dessas políticas:

-RPT - O senhor disse uma vez que o sistema de cotas, para combater a discriminação racial, não seria aceitável no Brasil. Por que não?

de S. Paulo". Além disso, desde janeiro de 2001, o Ministério da Educação, por meio do então secretário de educação superior, Antônio MacDowell de Figueiredo, já se posicionava contra as cotas. Segundo o ex-secretário, "a Constituição impede qualquer tipo de discriminação positiva, que beneficia as minorias (...). Isso é uma questão de solução mais estrutural do que de medidas como cotas" ("FOLHA DE SÃO PAULO", 14 de janeiro de 2001, p. C2). Essa visão ou retórica demonstrou-se completamente falsa quando, em 26 de abril de 2012, o STF julgou constitucional o sistema de cotas raciais das universidades públicas brasileiras. 
FHC - Pode até ser. Temos que examinar em que circunstâncias.

-RPT - O Senhor disse que os brasileiros não gostam do sistema. Por quê? Ele não poderia ser utilizado, por exemplo, para facilitar o acesso dos negros à educação?

FHC - Há uma reação grande à ideia, porque ela implica deixar de lado a avaliação de mérito. Portanto, seria uma discriminação. A oposição à cota é muito grande, mesmo dentro do Ministério da Educação.

•RPT - Mas os movimentos negros são a favor.

FHC - Sim, são a favor. À medida que você amplia a educação, universaliza mesmo, a probabilidade de ascensão dos negros vai ser maior. Leva mais tempo, mas tem resultados. Não quero entrar na discussão do sistema de cotas, pela resistência que vai provocar, mas não sou contrário. Havendo duas pessoas em condições para se nomear para determinado cargo, sendo uma negra, eu nomearia a negra.

(...)

-RPT - A política oficial brasileira é de que não aceitamos o racismo.

FHC - Se fosse diferente, seria mais fácil lutar contra.

-RPT - Por isso mesmo, porque não há uma política oficial negativa contra a qual lutar, é que, talvez, uma ação afirmativa, como o sistema de cotas, seja necessária. Não lhe parece?

FHC - Na questão da universidade - que é onde, basicamente, se aplicaria a cota - é complicado. Agora, acho importante haver um esforço grande no emprego. No Estado brasileiro, a discriminação caiu muito.

-RPT - O Estado, nesse particular, estaria melhor do que o mercado?

FHC - Está melhor do que o mercado. Veja o Itamaraty - começa a ter diplomatas negros. Nas Forças Armadas, há muitos negros. As Forças Armadas, nesse aspecto, são verdadeiramente democráticas. 
-RPT - Há generais negros?

FHC - Talvez não generais. Há um coronel, no meu gabinete, negro. Não é mulato, é negro. É coronel e está no meu gabinete. Espero que possa ser general, porque acho importante, por essa necessidade de uma ação afirmativa. (...) (CARDOSO apud TOLEDO, 1998: p. 328-330).

A ambiguidade das respostas do ex-presidente, embasadas em justificativas fugidias, demonstra a indecisão em instituir as ações afirmativas como políticas públicas. Valendo-se de argumentos contraditórios, o ex-presidente Fernando Henrique Cardoso procura encobrir sua posição ("Não quero entrar na discussão do sistema de cotas, pela resistência que vai provocar, mas não sou contrário"), mas logo em seguida, na mesma entrevista, deixa transparecer reservas quanto à aplicabilidade dessas políticas nas universidades públicas: "Na questão da universidade - que é onde, basicamente, se aplicaria a cota - é complicado. Agora, acho importante haver um esforço grande no emprego". A adesão do presidente Fernando Henrique Cardoso em relação às políticas de ações afirmativas, não foi extensiva às políticas de cotas.

Essa posição foi mantida em outras falas públicas do ex-presidente, como podemos notar na entrevista dada ao jornalista Ali Kamel, então diretor executivo de jornalismo da Rede Globo de Televisão. Sem desconsiderar a presença da discriminação racial no Brasil, FHC assevera que tal reconhecimento não corresponde a adoção de políticas focalistas: “... daí a enrijecer o espírito com cotas vai uma distância grande e nela mora o perigo. Eu prefiro, por exemplo, a solução dada no Itamaraty [bolsas para estudantes negros se aperfeiçoarem para o concurso de admissão à carreira de diplomata] do que a rigidez de somar não sei quantos pontos às notas de quem for 'negro' ou 'índio'" (CARDOSO apud KAMEL, 2006, p. 38).

Portanto, não é sem razão que no discurso do ex-ministro da Justiça da administração FHC, José Gregori, na III Conferência Mun- 
dial Contra o Racismo, realizada em Durban, África do Sul, no ano de 2001, não tenha constado nenhuma proposta sobre sistema de cotas para estudantes negros nos vestibulares das universidades públicas brasileiras, apesar de o termo ação afirmativa integrar o pronunciamento do ministro. Talvez por isso o antropólogo Adailton Silva e outros pesquisadores afirmaram que "foi a partir dos trabalhos preparatórios para a conferência mundial de Durban que as ações afirmativas começaram a ser pensadas seriamente como instrumentos para a redução da desigualdade racial no Brasil" (SILVA et.al., 2009, p. 36). Contudo, como afirmamos antes, no governo FHC, as políticas de ação afirmativa ficaram mais para o plano simbólico que para o plano das mudanças e práticas concretas, ou seja, foram mais protocolares e formais que substantivas.

\section{Políticas de Promoção da Igualdade no Governo Lula: a raça subsumida na classe social?}

No final da administração FHC, entre 2001 e 2002, havia debates febris no que diz respeito à discussão sobre a inclusão da população negra no ensino superior público brasileiro. Em realidade, esses debates foram recorrentes ao longo dessa década. As reivindicações dos movimentos negros visando a aumentar a presença de afro-brasileiros no ensino público obtiveram algumas respostas positivas nesse período. A despeito das fortes pressões em sentido contrário, especialmente pressões do mainstream da imprensa (Cf. MARTINS, 2005) e de parte significativa da intelectualidade brasileira (Cf. SANTOS, 2007), algumas universidades estaduais, como a Universidade do Estado do Rio de Janeiro (UERJ) e a Universidade Estadual do Norte Fluminense Darcy Ribeiro (UENF), no ano de 2001, e a Universidade Estadual da Bahia (UNEB), no ano de 2002, começaram a implementar políticas de ações afirmativas de ingresso no ensino superior para estudantes negros, por meio do sistema de cotas. 
A Universidade de Brasília (UnB) foi a primeira instituição federal de ensino superior brasileira a aprovar o sistema de cotas para estudantes negros e indígenas em seu vestibular, em 6 de junho de 2003, e a implementá-lo no segundo semestre de 2004. Não somente isso, a UnB foi também a primeira universidade federal brasileira que começou a discutir a necessidade de ações afirmativas como políticas de combate ao racismo, quando essa instituição hospedou o seminário internacional Multiculturalismo e racismo, citado anteriormente. Como a UNEB, a decisão da UnB de implementar uma política de ação afirmativa para estudantes pertencentes a grupos raciais e étnicos discriminados foi por meio da sua autonomia universitária. Ou seja, a política de ação afirmativa da UnB foi aprovada pelos professores-membros do seu Conselho de Ensino, Pesquisa e Extensão (CEPE). Não havia, nesta época, nenhuma norma legal que obrigava as universidades públicas federais a implementarem políticas de ações afirmativas para estudantes negros, como a recentíssima Lei no 12.711 , de 29 de agosto de $2012^{21}$.

Após a aprovação do sistema de cotas na UnB, houve crescimento significativo das políticas de ação afirmativa de ingresso no ensino superior para vários grupos raciais e sociais que são discriminados no Brasil. Desse modo, essa universidade serviu

${ }^{21}$ Essa lei "Dispõe sobre o ingresso nas universidades federais e nas instituições federais de ensino técnico de nível médio e dá outras providências". Segundo ela: "Art. 1ํㅗs instituições federais de educação superior vinculadas ao Ministério da Educação reservarão, em cada concurso seletivo para ingresso nos cursos de graduação, por curso e turno, no mínimo 50\% (cinquenta por cento) de suas vagas para estudantes que tenham cursado integralmente o ensino médio em escolas públicas. Parágrafo único. No preenchimento das vagas de que trata o caput deste artigo, 50\% (cinquenta por cento) deverão ser reservados aos estudantes oriundos de famílias com renda igual ou inferior a 1,5 salário-mínimo (um salário-mínimo e meio) per capita. (...). Art. $3^{\circ}$ Em cada instituição federal de ensino superior, as vagas de que trata o art. 1ํㅓㅁ desta Lei serão preenchidas, por curso e turno, por autodeclarados pretos, pardos e indígenas, em proporção no mínimo igual à de pretos, pardos e indígenas na população da unidade da Federação onde está instalada a instituição, segundo o último censo do Instituto Brasileiro de Geografia e Estatística (IBGE). (...)”. Extraído de: http://www.planalto.gov.br/CCIVIL_03/_Ato20112014/2012/Lei/L12711.htm. Acessado em 01 de setembro de 2012. 
como modelo inspirador e incentivador para a aprovação dessas políticas em outras instituições públicas de ensino superior no Brasil. Por exemplo, em julho de 2003, primeiro ano da administração do presidente Lula (2003 a 2010), somente aquelas quatro universidades públicas, citadas nos dois últimos parágrafos, tinham aprovado o sistema de cotas para estudantes negros. Cinco anos depois, em dezembro de 2008, ou seja, cinco anos de administração do presidente Lula, já existiam no Brasil 84 (oitenta e quatro) instituições públicas de ensino superior - tais como faculdades ou universidades municipais, estaduais e federais, assim como institutos federais de educação, ciência e tecnologia - que tinham implementado o sistema de cotas com recortes racial, étnico, social ou algum tipo de ação afirmativa de ingresso e/ou permanência para estudantes negros, indígenas, portadores de deficiência física, de baixa renda e/ou de escolas públicas (SANTOS et al, 2008, p. 920). Hoje, outubro de 2012, há 150 (cento e cinquenta) instituições públicas de ensino superior com algum tipo de ação afirmativa de ingresso nesse grau de ensino (Cf. VAZ, 2012).

Portanto, a luta dos movimentos negros brasileiros, associada à conjuntura internacional de renovação da pauta de combate ao racismo, manifestada na III Conferência Mundial contra o Racismo, realizada em 2001, fortaleceu, no Brasil, a discussão sobre a necessidade de implementação de ações afirmativas para a população negra no ensino superior público. Assim, ao que tudo indica, a partir do início do século XXI, a questão racial definitivamente foi incluída agenda nacional brasileira.

Esse quadro emergente realocou a questão racial na agenda política em outro patamar, passando a integrar os programas dos candidatos a presidente da República, em 2002. Vários postulantes ao cargo a chefe de Estado, inclusive o presidente eleito na época, Luiz Inácio Lula da Silva, apresentaram propostas de combate ao racismo e de inclusão da população negra nas áreas de prestígio, poder e mando, por meio de ações afirmativas. Após tomar posse, o presidente Lula criou, em 21 de março de 
$2003{ }^{22}$ a Secretaria Especial de Políticas de Promoção da Igualdade Racial (Seppir), resultado das reiteradas manifestações dos movimentos negros. No discurso de instalação da Seppir, Lula ratificou oficialmente o reconhecimento por parte do Estado brasileiro de que há discriminação racial contra os negros no Brasil, algo que o governo do presidente Fernando Henrique Cardoso (1995 à 2002) já havia feito. Desse modo, enquanto foi chefe de Estado brasileiro, Luiz Inácio Lula da Silva manteve o discurso que havia se instaurado no governo anterior, desfazendo a ideia de que no Brasil reina uma democracia racial: ${ }^{23}$

Pelo menos metade da população brasileira vem sendo prejudicada por essa situação [de discriminação]: a metade negra do nosso povo. Ela não é somente negra - é em sua grande maioria pobre. Mais de 64 por cento dos pobres e pelo menos 70 por cento dos indigentes são negros, como também a maior parte dos desempregados e subempregados do país também são negros. (...) Essa situação injusta e cruel é produto da nossa história - da escravidão que durou quatro séculos no Brasil, deixando marcas profundas em nosso convívio social -, mas é também resultado da ausência de políticas públicas voltadas para superá-la. 0 Estado brasileiro não deve ser neutro em relação às questões raciais. Cabe a ele assegurar a todos os brasileiros e brasileiras igualdade de oportunidades na busca de melhores condições de vida. (...) Ao nascer, a nova Secretaria [Seppir] dá a devida importância à promoção da igualdade racial no nosso país e abre espaço para a efetiva integração de projetos e ações em todo o conjunto de Governo (SILVA apud BRASIL/SEPPIR, 2003, p. 6).

Com esse pronunciamento, o presidente Lula cumpria algumas promessas, balizado pelas reivindicações dos movimentos negros. Além da Seppir, o então comandante do Estado brasileiro

${ }^{22}$ Lembramos aqui que o dia 21 de março é outra data histórica para os movimentos negros brasileiros. É o Dia Internacional de Combate à Discriminação Racial.

${ }^{23}$ Conforme Santos (2006), o discurso oficial de que o Brasil era uma democracia racial, de que havia harmonia racial neste país, foi recorrente até a primeira metade da década de noventa do século XX, com o governo Itamar Franco (1993-1994). 
enviou ao Congresso Nacional o Projeto de Lei $\mathrm{n}$ - 3.627, de 20 de maio de 2004, que visava instituir o "Sistema Especial de Reserva de Vagas para estudantes egressos de escolas públicas, em especial negros e indígenas, nas instituições públicas federais de educação superior e dá outras providências".

Em relação ao PL nº 3627/2004, ele estabelecia que:

Art. $1^{\circ}$ As instituições públicas federais de educação superior reservarão, em cada concurso de seleção para ingresso nos cursos de graduação, no mínimo, cinquenta por cento de suas vagas para estudantes que tenham cursado integralmente o ensino médio em escolas públicas.

Art. $2^{\circ}$ Em cada instituição de educação superior, as vagas de que trata o art. $1^{0}$ serão preenchidas por uma proporção mínima de autodeclarados negros e indígenas igual à proporção de pretos, pardos e indígenas na população da unidade da Federação onde está instalada a instituição, segundo o último censo da Fundação Instituto Brasileiro de Geografia e Estatística - IBGE.

Em 18 de fevereiro de 2009 esse projeto de lei foi arquivado na Mesa Diretora da Câmara dos Deputados ${ }^{24}$, uma vez que o governo Lula não exigiu da sua base governista, nessa Casa do Congresso, que ela desse apoio concreto à aprovação desse projeto. Ou seja, o governo Lula não utilizou "o rolo compressor governista", tantas vezes mobilizado quando o assunto era de seu interesse. Em certo sentido, isso indica que, para o governo Lula, a pauta da igualdade racial não era tão importante assim como imaginavam e/ou afirmavam os defensores de políticas de promoção da igualdade racial.

\footnotetext{
${ }^{24}$ Contudo, devemos lembrar que já havia na Câmara dos Deputados o PL no 93/1999, que propunha políticas semelhantes às do projeto $\mathrm{n}$ o 3627/2004. Mais ainda, este último foi apensado ao primeiro, em 23/06/2004, embora também conste no site da Câmara a informação do seu arquivamento. Extraída de: http://www.camara.gov.br/proposicoesWeb/fichadetramitacao?idProposicao=254614, em 13 de maio de 2011.
} 
Por outro lado, não se pode esquecer que a criação da Secretaria Especial de Políticas de Promoção da Igualdade Racial (Seppir) é um dos argumentos considerados, por muitos, como incontestes de que o governo Lula apoiava tais políticas. Segundo a pesquisadora Marilene de Paula,

...esse governo [Lula] apontava que políticas universais não eram suficientes para enfrentar as desigualdades sensíveis a "raça", quebrando de forma clara a postura de neutralidade. (...) Para o governo a criação de um órgão específico dentro da máquina pública afirmava a necessidade de combate ao racismo e suas perversas consequências por meio de políticas públicas focais (...) (PAULA 2011, p. 63).

Todavia, os que sustentam o argumento de que a criação da Seppir é um forte indício de que o governo Lula apoiava sem tergiversar políticas de promoção da igualdade racial, esquecem que esse governo teve início em $1^{\text {o }}$ de janeiro de 2003, com a criação de todos os seus ministérios e secretarias especiais a partir desta data. Tais como a Secretaria Especial de Políticas para as Mulheres (SPM), a Secretaria Especial de Aquicultura e Pesca (SEAP), entre outras, menos a Seppir, que somente foi criada em 21 de março de 2003, ou seja, dois meses e 21 dias depois do início do governo Lula. Vale enfatizar que a Seppir foi criada porque houve forte pressão dos movimentos sociais negros pela criação de um ministério que discutisse a questão racial no governo Lula (Cf. SANTOS, 2007), demanda já fortemente esboçada no governo Fernando Henrique Cardoso. Segundo a ativista Edna Roland, fundadora e militante da ONG "Fala Preta! - Organização de Mulheres Negras", que foi relatora da III Conferência Mundial contra o Racismo, Discriminação Racial, Xenofobia e Intolerância Correlata,

Quando se iniciou o governo do Fernando Henrique houve um grupo de militantes, do qual eu fiz parte, que foi ter um diálogo com Fernando Henrique, solicitando a criação 
de um mecanismo institucional. Depois da eleição, tivemos um jantar com o presidente e a gente pedia um mecanismo institucional que fosse mais abrangente que a Fundação [Cultural] Palmares. A gente considerava que a Palmares era uma fundação cultural, o limite da ação dela era a cultura, e a gente precisava de um órgão que pudesse dialogar com todas as áreas relevantes para a implementação de políticas públicas para a população negra. E o Fernando Henrique e o [Francisco] Weffort, que era o ministro da Cultura, tentaram dizer que a [Fundação Cultural] Palmares era suficiente. E a gente dizia que o estatuto da Palmares não permitia. $\mathrm{Ou}$ se mudava o estatuto ou se criava um novo órgão, porque a Palmares não dava conta do que a gente precisava. A gente precisava de políticas para todas as áreas: educação, saúde, trabalho, etc. 0 [Nelson] Jobim, que era na época o ministro da Justiça, concordou conosco. Ele disse: "eles têm razão, o que eles querem a Palmares não responde". E eles ficaram de pensar e só depois da Marcha de novembro é que o Fernando Henrique veio a criar o tal do GTI. (ROLAND apud PAULA, 2010, p. 53-54).

O governo FHC resistiu e não criou tal instituição. 0 governo Lula, mais sensível aos movimentos sociais, após resistir, cedeu à pressão e criou a Seppir. Porém, essa secretaria nunca teve uma estrutura de funcionamento digna, não tendo até o presente momento um quadro de pessoal de funcionários concursados, ou seja, um quadro de pessoal próprio, para trabalhar nessa secretaria. Os funcionários que trabalham na Seppir são, em geral, emprestados de outros órgãos públicos. Abreviadamente, falta-lhe, até hoje, recursos humanos.

Além dessas deficiências, há inegável carência de recursos financeiros. Quando comparada com a Secretaria Especial de Políticas para as Mulheres (SPM) e Secretaria Especial de Direitos Humanos (SEDH), até o presente momento, a Seppir é a secretaria que, historicamente, recebe o menor orçamento. Segundo o cientista político Alexandre Ciconello (2011, p. 88), entre 2003 e 2010, o investimento acumulado da SEDH foi de R $\$ 656$ milhões, 
o da SPM foi R $\$ 255,1$ milhões e o da Seppir foi de R\$147,04 milhões. Ou seja, nesse período, os investimentos feitos na SEDH e na SEP foram, respectivamente, 4,46 e 1,73 vezes maiores que os feitos na Seppir.

Não bastasse essa diferença de investimento entre essas secretarias, a Seppir também é a que menos fez execução orçamentária. Em 2004 e 2010, executou, respectivamente, R\$ 17,09 milhões e R\$ 19,14 milhões. Já a SPM em 2004 e 2010, executou, respectivamente, $\mathrm{R} \$ 19,70$ milhões e $\mathrm{R} \$ 74,25$ milhões. Por outro lado, a SEDH executou nos mesmos anos, respectivamente, $\mathrm{R} \$ 62,11$ milhões e R\$164,44 milhões, conforme se pode ver no gráfico abaixo, citado por Ciconello (2011, p. 88).

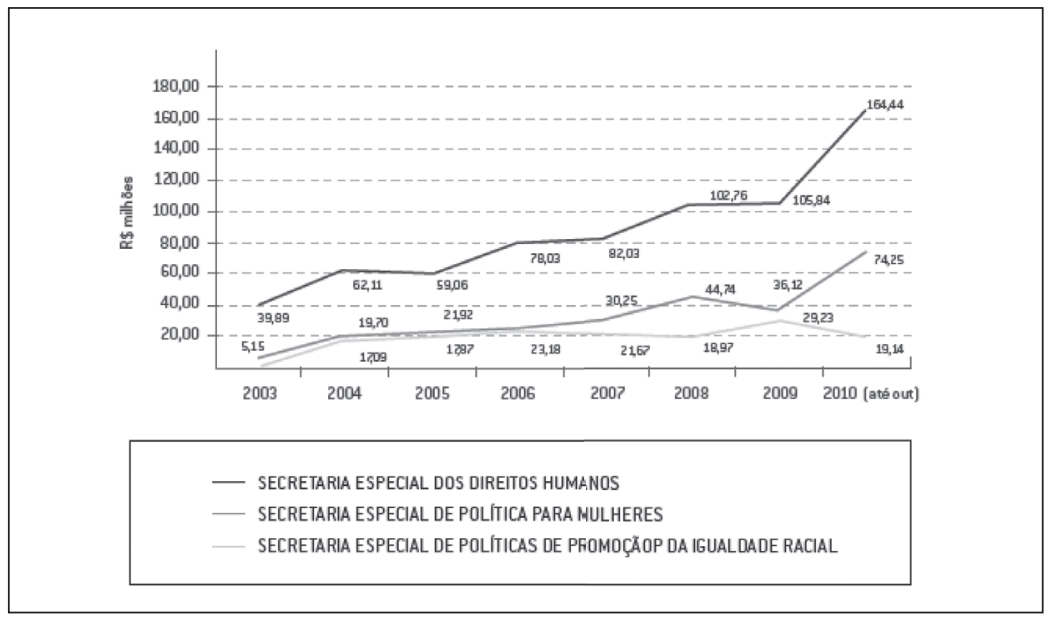

Grafico 1 - Execução financeira de secretarias especiais do Governo Federal selecionadas - valores reais atualizados pelo IGP-DI/FGV (ago/2010)

Fonte: Siga Brasil/Senado Elaboração INESC. Nota: A execução financeira é calculada a partir da soma dos valores pagos "restos a pagar - não processados pagos" de um mesmo exercício financeiro

Por outro lado, para alguns pesquisadores o governo Lula experimentou uma fase de aprofundamento da questão racial, ampliando os limites de atuação do Estado brasileiro nesse quesito. Para esses autores a área educacional foi a que apresentou mais 
avanços significativos em termos de implementação de políticas de ação afirmativa. Segundo Marilene de Paula,

A superação das desigualdades raciais passa necessariamente pela intervenção do Estado, a partir de políticas públicas consistentes, articuladas e com recursos definidos. No governo Lula, ao contrário do antecessor FHC, as políticas de na área racial tiveram mais visibilidade e programas em escala foram implementados. Um avanço significativo ocorreu no ensino superior e em setores anteriormente resistentes à implementação de políticas nessa área (PAULA, 2011, p. 73).

Para sustentar a afirmação acima a pesquisadora Marilene de Paula (2011, p. 66) cita dois exemplos de políticas de ações afirmativas implementadas pelo governo Lula nessa área: a) o Programa Universidade para Todos (PROUNI); e b) a Lei $\mathrm{n}$ o $10.639 / 2003$.

Contudo, pensamos que tais argumentos são muito frágeis para sustentar a tese de que houve uma fase de aprofundamento da questão racial no governo Lula (assim como políticas de ação afirmativa foram implementadas em escala), no sentido de superação do racismo. Em primeiro lugar, de acordo com as pesquisadoras Luciana Jaccoud e Nathalie Beghin (2002), a Lei $\mathrm{n}^{\mathrm{o}}$ 10.639/2003, ao ser executada estaria no campo das ações valorizativas. Portanto, não faremos comentários sobre a mesma, visto que a sua implementação não implica execução de políticas públicas de ação afirmativa.

Em segundo lugar, com relação ao PROUNI, não há dúvida de que ele é um programa de ação afirmativa de inclusão no ensino superior, por meio da técnica de implementação do sistema de cotas. Criado por meio da Medida Provisória (MP) no 213, de 10 de setembro de 2004, que foi convertida na Lei n. ${ }^{\circ}$ 11.096, de 13 de janeiro de 2005, o Programa Universidade para Todos (PROUNI), sob a gestão do Ministério da Educação, concede bol- 
sas de estudo integrais (100\%) e parciais (50\% e 25\%) para estudantes que tenham cursado o ensino médio completo em escolas da rede pública brasileira ou em instituições privadas, desde que na condição de bolsista integral. Este programa estabelece também uma subcota, entre estudantes de escola pública, que sejam autodeclarados negros ou indígenas. Conforme o inciso II do art. 7ํ dessa lei, há também um "percentual de bolsas de estudo destinado à implementação de políticas afirmativas de acesso ao ensino superior de portadores de deficiência ou de autodeclarados indígenas e negros", sendo que este percentual deve "ser, no mínimo, igual ao percentual de cidadãos autodeclarados indígenas, pardos ou pretos, na respectiva unidade da Federação, segundo o último censo da Fundação Instituto Brasileiro de Geografia e Estatística - IBGE”.

O programa tem obtido sucesso em termos de acesso ou inclusão de alunos de baixa renda no ensino superior privado brasileiro, inclusive alunos autodeclarados negros, que, no ano de 2010, eram 47,25\% dos bolsistas. Conforme Marilene de Paula,

O Programa é o grande responsável pela elevação da taxa de estudantes no ensino superior, disponibilizando 1.128.718 bolsas (integrais ou parciais), destas 748.788 foram preenchidas, 66\%. Apesar do não preenchimento do total de bolsas é grande a procura pelo Programa, sendo 5.548.746 inscritos de 2005 a 2010. (...) De 2005 a 2010, 353.813 bolsas foram distribuídas para estudantes negros (pretos e pardos) (PAULA, 2011, p. 66-67).

Não se pode negar a importância desse processo de inclusão de alunos negros de baixa renda no ensino superior brasileiro. Os dados acima são significantes. Contudo, como o "Programa Diversidade na Universidade", que foi criado no governo FHC, o PROUNI, ao que tudo indica, foi mais uma tentativa do Poder Executivo, ou seja, do governo federal, de retirar a pressão constante e crescente, especialmente dos movimentos sociais negros, 
pela implementação do sistema de cotas para estudantes afro-brasileiros nas universidades públicas. Não somente isso, ele representou um indicativo de que o governo Lula de fato não tinha real vontade política de aprovar políticas de ação afirmativa de acesso ao ensino público superior para os estudantes negros.

Estas hipóteses, que necessitam de pesquisa mais profundas para serem confirmadas, têm fortes indícios em pelo menos dois fatos. Primeiro, apesar de o governo Lula enviar para o Congresso Nacional o Projeto de Lei no 3.627, de 20 de maio de 2004, que visava a instituir um sistema cotas para estudantes negros e indígenas nas universidades públicas, esse governo não se empenhou, ou melhor, não mobilizou a sua base parlamentar para aprová-lo. A omissão do governo Lula também ficou evidente quanto à falta de apoio à versão do Estatuto da Igualdade Racial, que continha propostas de sistema de cotas: a) nas universidades públicas brasileiras, para estudantes negros; b) para atores e figurantes afro-brasileiros nos filmes e programas veiculados pelas emissoras de televisão, nas peças publicitárias para televisão e cinema e nos contratos de realização de filmes, programas ou quaisquer outras peças de caráter publicitário para os órgãos e entidades da administração pública; c) nas legendas dos partidos políticos ou nas coligações partidárias, para candidatos negros, como demonstram Santos, Santos e Bertúlio (2011).

Segundo, o PT, partido do próprio presidente e principal força política do governo Lula, apesar de discursivamente apoiar as políticas de ação afirmativa para a população negra, na prática não demonstrou interesse em apoiá-las. Isto ficou patente no período de pré-julgamento da Arguição de Descumprimento de Preceito Fundamental (ADPF) n. $\stackrel{0}{186}$, citada anteriormente. Antes do julgamento final dessa Arguição, várias instituições públicas e privadas protocolaram petições no STF solicitando participar do desse julgamento como Amicus Curiae (amigo da corte), para defender o sistema de cotas da UnB. O PT, apesar de avisado pelo Advogado Humberto Adami para peticionar no STF e também defender o sistema de co- 
tas, perdeu o prazo para tal. Conforme o advogado Humberto Adami publicou, no dia 18 de novembro de 2011, em seu blog,

0 Partido dos Trabalhadores (PT) está fora da ADPF 186, ação no STF que decide a constitucionalidade das ações afirmativas para negros na UnB. 0 despacho do Ministro Ricardo Lewandovski (...) considera fora do prazo o pedido de ingresso do partido político no processo, na qualidade de amigo da corte. Conversei pessoalmente sobre o assunto, insistindo mesmo, com a Secretária Nacional de Combate ao Racismo do PT, Cida Abreu, bem como com o ex-ministro da SEPPIR, Elói Ferreira, e Martvs Chagas, dando conta da urgência do partido político - ... - ingressar nos autos da ação para fazer frente à ação do DEM. Me dispus inclusive a ir ao Congresso de Negras e Negros do PT para falar da proposta em palestra, onde fui "convidado e desconvidado" por não ser membro do partido. (... ${ }^{25}$.

Como se observa na citação acima, não somente a então Secretária Nacional de Combate ao Racismo do PT, Cida Abreu, foi comunicada da necessidade do PT peticionar no STF, dentro do prazo legal, para defender o sistema de cotas raciais, como o então ministro da Seppir, Elói Ferreira. Apesar disso, nada foi feito em tempo hábil, ante, ao que tudo indica, a falta de interesse desse partido com relação a esse tema. Ou seja, a questão racial e políticas para acabar e/ou minimizar as desigualdades raciais no Brasil têm sido consideras residuais para o PT.

Por fim, há outro fato que nos indica que o PROUNI era mais um paliativo que uma política de ação afirmativa consistente para o ingresso dos negros nos espaços de prestígio, poder e mando. Os ferozes opositores do sistema de cotas para estudantes negros no ensino público superior, como os cientistas sociais Yvonne Maggie, Peter Fry, entre outros, não contestaram o PROUNI, apesar de esse programa ter cotas raciais. E não contestaram porque esses cientistas sociais sabem que as universidades priva-

${ }^{25}$ Extraído de: http://humbertoadami.blogspot.com.br/2011/11/pt-fora-das-cotas-no-stf.html. Acessado 14 de outubro de 2012. 
das brasileiras, em geral, não têm a mesma qualidade de ensino, pesquisa e extensão que as públicas. Dessa forma, procurou-se incluir os estudantes negros nas universidades e faculdades privadas. Ou seja, ao que parece, o PROUNI foi uma válvula de escape à pressão pela implementação do sistema de cotas nas universidades públicas, que crescia consideravelmente em nível nacional, como foi visto anteriormente.

Portanto, mesmo num governo de centro-esquerda, orientado por uma visão de mundo mais pró-social que pró-mercado, como foi o do presidente Lula, a implementação de ações afirmativas para afro-brasileiros não teve apoio convicto, isto é, concreto e consistente, visto que durante a sua administração houve apenas a execução de uma política de ação afirmativa inclusiva no ensino superior: o PROUNI.

\section{Conclusão}

Quando comparamos os governos FHC (1995 à 2002) e Lula (2003 à 2010), no que diz respeito a propostas, apoio, aprovação e execução de políticas de ação afirmativa inclusivas para a população negra, ou seja, políticas públicas focalizadas que proporcionam o acesso desse grupo racial aos espaços de prestígio, poder e mando, parece não haver grandes diferenças entre esses governos. No governo Lula, com orientação mais pró-proteção social, só houve uma política concreta de ação afirmativa, mas muito frágil, como visto anteriormente: o PROUNI. No governo FHC, com orientação pró-mercado, neoliberal, evitou-se a proposição, a aprovação e a execução de políticas de ação afirmativa que garantisse, de fato, a inclusão dos afro-brasileiros nos espaços de prestígio, poder e mando.

Em termos de busca da igualdade racial, se analisássemos esses dois governos somente olhando as suas ações no que diz respeito à implantação e à execução de ações afirmativas, poderíamos 
chegar à mesma conclusão da filósofa e ativista dos movimentos feminista e negro, Sueli Carneiro. No ano 2000, no momento em que a questão racial estava se consolidando na agenda política nacional, esta intelectual orgânica afirmou, em entrevista à revista "Caros Amigos": "Sabe, entre a esquerda e a direita, sei que continuo preta" (CAROS AMIGOS, 2000, P. 29). Ou seja, discriminada e excluída por ser preta.

Da perspectiva de execução apenas de ações afirmativas, ante as características da sociedade brasileira, especialmente a de ser marcada pelo mito da democracia racial, pode ser que para governos neoliberais e governos pró-proteção social os negros continuem estigmatizados e sem políticas públicas que levem em consideração a exclusão racial. Mas da perspectiva da promoção da igualdade racial, como a definimos no início desse artigo, talvez haja uma interrogação, ou melhor, haja uma tendência a se reconhecer positivamente e valorizar governos que implantam políticas redistributivas ou pró bem-estar social.

Contudo, há autores que afirmam que o governo Lula foi uma continuidade do governo FHC na área econômica. Segundo os economistas Lauro Mattei e Luis Felipe Magalhães,

fica evidente que a política econômica no início do governo Lula não é somente uma continuidade como também uma tentativa de aprofundar o uso dos mecanismos ortodoxos oriundos da filosofia macroeconômica neoliberal, a qual encontra guarida no Fundo Monetário Internacional, Banco Mundial, bem como na própria Federação dos Bancos Brasileiros (Febraban) (...). (MATTEI e MAGALHÃES, 2011, p. 139).

Talvez, por isso mesmo, possa-se até concordar com a assertiva da ativista Sueli Carneiro, visto que a esquerda brasileira também poderia aplicar políticas neoliberais. A esse respeito, Perry Anderson afirmou que "o neoliberalismo havia começado tomando a social-democracia como uma inimiga central, em 
países do capitalismo avançado, provocando uma hostilidade recíproca. Depois, os governos social-democratas se mostraram os mais resolutos em aplicar políticas neoliberais" (ANDERSON, 1995, p. 14). Isso indica que o mesmo pode ter acontecido com o governo Lula.

Contudo, se o governo Lula foi neoliberal na área econômica, como afirmam Mattei e Magalhães (2011), ao que parece não o foi de forma pura em sentido amplo, ou seja, em todas as suas áreas. 0 receituário neoliberal ${ }^{26}$ seguido pelo governo $\mathrm{FHC}$ parece não ter sido o mesmo seguido pelo governo Lula, até porque nas áreas do emprego, trabalho e salário, ao que tudo indica, o governo Lula teve uma orientação pró-proteção social. Enquanto no governo FHC houve elevação do desemprego, que passou de 4,8\% em 1994 para 8,3\% em 2002, no último ano do governo Lula, em 2010, essa taxa caiu para de 6,7\%. Deve-se destacar que no primeiro ano do governo Lula, em 2003, a taxa de desemprego foi $12,4 \%{ }^{27}$. Além disso, foram criados mais 14 milhões de emprego, entre 2003 e 2010. Por outro lado, no governo FHC houve redução do salário mínimo, que em 1994 era de U\$ 110 e caiu para U\$ 80 em 2002 (Cf. MATTEI e MAGALHÃES, 2011, p. 138; CICONELLO, 2011, p. 81). No governo Lula houve um movimento inverso, ou melhor, um constante aumento real do salário mínimo, que no final do seu governo correspondia a U\$291 28 . Ou seja, esse salário mais que triplicou durante a sua administração.

${ }^{26}$ Conforme Perry Anderson (1995, p. 10 e 11) o receituário dos neoliberais seria uma combinação de ações: estabilidade monetária; disciplina orçamentária; contenção dos gastos com bem-estar; restauração da taxa "natural" de desemprego; quebra dos sindicatos; redução dos salários, entre outras.

27 Extraído de: http://www1.folha.uol.com.br/poder/1039681-taxa-de-desemprego-media-em-2011-foi-de-6-aponta-ibge.shtml. Acessado em 07 de outubro de 2012.

28 Extraído de: http://brasilfatosedados.wordpress.com/2010/10/01/renda-salario-minimo-em-dolaru-evolucao-nominal-e-crescimento-percentual-por-mandato-1995-2010/. Acessado em 07 de outubro de 2012. 
O progressivo ganho real do salário mínimo no governo Lula implicou uma redução mais que considerável na desigualdade social brasileira. Para o Brasil, o índice de Gini, que mede desigualdade de renda, demonstra que houve uma redução dessa desigualdade, entre 1995 e 2009. Contudo, a redução mais acentuada ocorreu justamente durante a administração do governo Lula. Em 2002, o índice de Gini era 0.586 caindo para 0.538 em 2009 , conforme se pode ver no gráfico abaixo, citado por Ciconello (2011, p. 82). No ano de 2011 o índice caiu novamente, para 0,527 , indicando que houve nova redução da desigualdade (NERI, 2012, p. 8).

Segundo o pesquisador e ex-presidente do IPEA, Marcelo Neri, a renda dos brasileiros mais pobres, entre 2001 e 2011, aumentou muito mais que a dos mais ricos. "De acordo com a PNAD, a desigualdade de renda no Brasil vem caindo continuamente desde 2001. Entre 2001 e 2011, a renda per capita dos $10 \%$ mais ricos aumentou $16,6 \%$ em termos acumulados, enquanto a renda dos mais pobres cresceu notáveis 91,2\%". Mais ainda, para este pesquisador, a redução da desigualdade e da pobreza no período supracitado deve-se principalmente à elevação da renda dos brasileiros, especialmente a renda obtida por meio do trabalho formal. Além disso, nesse mesmo período, constatou-se que a renda dos negros foi uma das que mais aumentou: "a renda daqueles que se identificam com pretos e pardos sobe $66,3 \%$ e $85,5 \%$, respectivamente, contra 47,6\% dos brancos" (NERI, 2012, p.7). 


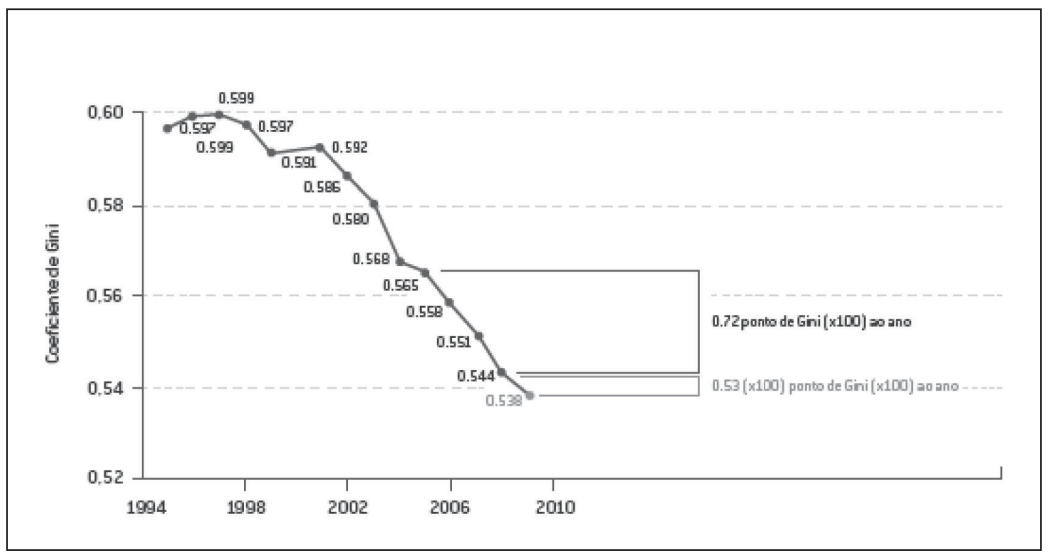

Gráfico 2 - Coeficiente de Gini: 1995 a 2009

Fontes: PNAD Microdados 1995 a 2009. Nota: Brasil, salvo área rural dos seguintes estados: Acre, Amapá, Amazonas, Para, Rondônia e Roraima. Elaboração: IPEA.

Portanto, se em termos de proposição e implementação de políticas de ações afirmativas para a população negra não há diferenças significativas entre os dois governos brasileiros que foram comparados neste artigo, o do presidente FHC, de orientação neoliberal, e o do presidente Lula, de orientação pró-proteção social, ante a desconsideração do racismo como causador de desigualdades profundas, quando se verificam os dados citados nos parágrafos anteriores, parece não haver dúvidas de que governos de orientação pró-proteção social tendem a ser menos excludentes e proporcionam mais justiça do ponto de vista da promoção da igualdade racial que os de orientação neoliberal.

\section{Referências Bibliográficas}


ANDERSON, Perry. "Balanço do neoliberalismo". In: SADER, Emir e GENTILI, Pablo. (Orgs.). Pós-neoliberalismo: as políticas sociais e o Estado Democrático. São Paulo: Paz e Terra, 1995.

BERNARDINO, Joaze, Santos, Sales Augusto dos e Silvério, Valter Roberto "Relações raciais em perspectiva". Sociedade e Cultura. Goiânia: Editora da UFG, 2009. v. 12, no 2: 215-222, jul./dez

BRASIL. Secretaria Especial de Políticas de Promoção da Igualdade Racial. Política Nacional de Promoção da Igualdade Racial. Brasília: Seppir, 2003.

Presidência da República. Construindo a Democracia Racial. Brasília: Ministério da Justiça, 1998.

Programa Nacional de Direitos Humanos. Brasília: Ministério da Justiça, 1996.

CARDOSO, Edson Lopes. "População negra e Congresso Nacional: projetos de lei em tramitação e aprovados". In População Negra em Destaque. São Paulo: CEBRAP, 1998.

CARDOSO, Fernando Henrique. "Pronunciamento do Presidente da República na abertura do seminário multiculturalismo e racismo". In SOUZA, Jessé (Org.). Multiculturalismo e racismo: uma comparação Brasil-Estados Unidos. Brasília: Paralelo 15, 1997.

Caros Amigos, São Paulo, ano 4, fev. 2000, p. 29.

CICONELLO, Alexandre. "Os Avanços e contradições das políticas de direitos humanos no governo Lula." In PAULA, Marilene de. (Org.). "Nunca antes na história desse país"...? Um balanço das políticas do governo Lula. Rio de Janeiro: Fundação Heinrich Böll, 2011.

DEMO, Pedro. "Focalização de políticas sociais. Debate perdido, mais perdido que a agenda perdida". Serviço Social e Sociedade. São Paulo: Cortez, ano 24, n. 76, p. 93-117, nov. 2003.

EXECUTIVA NACIONAL DA MARCHA ZUMBI (ENMZ). Por uma política nacional de combate ao racismo e à desigualdade racial: marcha Zumbi contra 0 racismo, pela cidadania e vida. Brasília: Cultura Gráfica e Ed., 1996.

FALEIROS, Vicente de Paula. "A Reforma do Estado no período FHC e as propostas do Governo Lula". In FALEIROS, Vicente de Paula et al. A era FHC e o Governo Lula: transição? Brasília/INESC, 2004.

FIGUEIREDO, Argelina Cheibub, LIMONGI, Fernando \& VALENTE, Ana Luzia. 
"Governabilidade e concentração de poder institucional: o Governo FHC". Tempo Social. Rev. Sociol. USP, S. Paulo, 11(2): 49-62, out. 1999

FRY, Peter. A Persistência da raça: ensaios antropológicos sobre o Brasil e a África Austral. Rio de Janeiro: Civilização Brasileira, 2005.

HASENBALG, Carlos A. Entre o mito e os fatos: racismo e relações raciais no Brasil. In MAIO, Marcos Chor e SANTOS, Ricardo Ventura (Org.). Raça, ciência e sociedade. Rio de Janeiro: FIOCRUZ, CCBB, 1996.

JACCOUD, Luciana de Barros; BEGHIN, Nathalie. Desigualdades raciais no Brasil: um balanço da intervenção governamental. Brasília: IPEA, 2002.

KAMEL, Ali. Não somos racistas: uma reação aos que querem nos transformar numa nação bicolor. Rio de Janeiro: Nova Fronteira, 2006.

Maggie, Yvonne. "Separados legalmente". 0 Globo. 1ํ de maio, caderno Opinião, 2012, p.7.

"Política de cotas e o vestibular da UnB ou a marca que cria sociedades divididas". Horizontes Antropológicos, Porto Alegre, ano 11, n. 23, p. 286291, jan./jun. 2005.

MAGGIE, Yvonne; FRY, Peter. "A reserva de vagas para negros nas universidades brasileiras". Estudos Avançados: revista do IEA da USP. São Paulo, v. 18, n. 50, p. 67-80, 2004.

MARTINS, André Ricardo Nunes. "Racismo e imprensa: argumentação no discurso sobre as cotas para negros nas universidades". In SANTOS, Sales Augusto dos (Org.). Ações afirmativas e combate ao racismo nas Américas. Brasília: MEC/SECAD, 2005.

MATTEI, Lauro e MAGALHÃES, Luis Felipe. "A Política Econômica durante o governo Lula (2003-2010): cenários, resultados e perspectivas". In PAULA, Marilene de. (Org.). "Nunca antes na história desse país"...? Um balanço das políticas do governo Lula. Rio de Janeiro: Fundação Heinrich Böll, 2011.

MEDEIROS, Carlos Alberto. "Abdias Nascimento: um Quixote vence os moinhos de vento". In População negra em destaque, CEBRAP, São Paulo, 1998.

MUNANGA, Kabengele. (Org.). Superando o racismo na escola. Brasília: Ministério da Educação/Secretaria de Educação Fundamental, 1999.

. "Identidade, cidadania e democracia: algumas reflexões sobre os discursos anti-racistas no Brasil". In: SPINK, Mary Jane Paris. A Cidadania em construção: uma reflexão transdisciplinar. São Paulo: Cortez, 1994.

NASCIMENTO, Abdias. Povo negro: a sucessão e a Nova República. Rio de Ja- 
neiro: IPEAFRO, 1985.

(Org.). 0 Negro revoltado. Rio de Janeiro: Nova Fronteira, 1982.

NASCIMENTO, Abdias; NASCIMENTO, Elisa Larkin. "O Negro e o Congresso Brasileiro". In MUNANGA, Kabengele (Org.). 0 Negro na sociedade brasileira: resistência, participação, contribuição. Brasília: Fundação Cultural Palmares-MINC, v. 1, 2004.

NERI, Marcelo Côrtes. "A Década Inclusiva (2001-2011): desigualdade, pobreza e políticas de renda". In INSTITUTO DE PESQUISA ECONÔMICA APLICADA (IPEA). Texto para discussão n. 155. Brasília: IPEA, 2012.

PAULA, Marilene de. "A promoção da igualdade racial na era Lula". In PAULA, Marilene de. (Org.). "Nunca antes na história desse país"...? Um balanço das políticas do governo Lula. Rio de Janeiro: Fundação Heinrich Böll, 2011.

Políticas de ação afirmativa para negros no governo Fernando Henrique Cardoso (1995-2002). Fundação Getúlio Vargas (FGV)/Centro de Pesquisa e Documentação de História Contemporânea do Brasil (CPDOC), Programa de Pós-Graduação em História, Política e Bens Culturais, Dissertação de Mestrado, abril, 2010.

SALLUM JR., Brasilio. "O Brasil sob Cardoso: neoliberalismo e desenvolvimentismo”. Tempo Social. Rev. Sociol. USP, S. Paulo, 11(2): 23-47, out. 1999.

SANTOS, Renato Emerson dos. "A Difusão do ideário anti-racista nos pré-vestibulares para negros e carentes". In SANTOS, Sales Augusto dos (Org.). Ações afirmativas e combate ao racismo nas Américas. Brasília: MEC/SECAD, 2005.

SANTOS, Sales Augusto dos. Movimentos Negros, Educação e Ações Afirmativas. Tese (Doutorado em Sociologia)-UnB, Brasília, ago., 2007.

"Who is black in Brazil?: a timely or a false question in brazilian race relations in era of affirmative action?" Latin American Perspectives. California, issue 149, v. 33, n. 4, July, p. 30-48, 2006.

SANTOS, Sales Augusto dos, SANTOS, João Vitor Moreno e BERTÚLIO, Dora Lúcia. 0 Processo de Aprovação do Estatuto da Igualdade Racial, Lei 12.288, de 20 de julho de 2010. Brasília: INESC, 2011.

SANTOS, Sales Augusto dos at. al. "Ações Afirmativas: polêmicas e possibilidades sobre igualdade racial e o papel do Estado". Revista Estudos Feministas, v. 16: 913-919, 2008.

SEMOG, Ele e NASCIMENTO, Abdias. Abdias Nascimento: o griot e as muralhas. Rio de Janeiro: Pallas, 2006.

SILVA, Adailton et al. "Entre o racismo e a desigualdade: da Constituição à pro- 
moção de uma política de Igualdade racial (1988-2008)" In JACCOUD, Luciana de Barros (Org.). A Construção de uma Política de Promoção da Igualdade Racial: uma análise dos últimos 20 anos. Brasília: IPEA, 2009.

SILVA, Ana Célia da. A discriminação do negro no livro didático. Salvador: EDUFBA, 2005.

SILVA, Jorge da Silva. "Política de ação afirmativa para a população negra: educação, trabalho e participação no poder". In VOGEL, Arno (Org.). Trabalhando com a diversidade no Planfor: raça/cor, gênero e pessoas portadoras de necessidades especiais. São Paulo: UNESP, Brasília: FLACSO do Brasil, 2001.

SKIDMORE, Thomas E. "EUA Bi-racial vs. Brasil Multirracial: o Contraste ainda é Válido?" Novos Estudos CEBRAP. São Paulo, no 34, p. 49-62, 1992.

SOUZA, Jessé. Multiculturalismo e racismo: uma comparação Brasil-Estados Unidos. Brasília: Paralelo 15, 1997.

SÜSSEKIND, Arnaldo. Convenções da OIT. São Paulo: LTr, 1994.

TOLEDO, Roberto Pompeu. O PRESIDENTE SEGUNDO o SOCIÓLOGO - ENTREVISTA DE FERNANDO HENRIQUE CARDOSO A ROBERTO POMPEU DE TOLEDO. São Paulo: Companhia das Letras, 1998.

VAZ, Leandro Farias. Uma Geografia das Ações Afirmativas no Ensino Superior: as cotas étnico-raciais na UEG e UFG. Dissertação (Mestrado em Geografia) - UFG/IESA, Goiânia, ago., 2012.

Recebido em 20/10/2014

Aprovado em 03/11/2014 